\title{
THE SOCIAL SPREAD OF ROMAN LUXURY: SAMPLING POMPEII AND HERGULANEUM'
}

\section{CONTENTS}

I. Introduction

II. Vital statistics 151

$\begin{array}{ll}\text { III. Sizes and distribution } & 156\end{array}$

IV. Residential and non-residential space $\quad 164$

$\begin{array}{ll}\text { V. Atria and peristyles } & 166\end{array}$

$\begin{array}{lr}\text { VI. Decoration } & 170\end{array}$

(a) The diffusion of decoration 173

(b) Decoration and function $\quad 176$

(c) The chronology of diffusion $\quad 180$

(d) From luxus to kitsch 184

$\begin{array}{ll}\text { VII. Finds } & 187\end{array}$

$\begin{array}{ll}\text { VIII. Conclusions } & 190\end{array}$

\section{INTRODUCTION}

Our friend, Lucius Lucullus, that great man, made what passed as a very neat reply to criticisms of the magnificence of his Tusculan villa: he had two neighbours, uphill an eques Romanus, downhill a freedman; considering that they had magnificent villas, he ought to be allowed what others of lower rank got away with. Don't you realise, Lucullus, that even their aspirations are your responsibility? ... The abuses of the leading men (principes) are bad enough; but what is worse is the way they have so many imitators. History shows that the leading men in society have always dictated its character. Whenever there has been a transformation of morals and manners (mutatio morum) among the social leaders, the same transformation has followed among the people (populus).

Gicero, de Legibus 3.30-1

1 The argument of this paper hangs closely together with those of three others: 'The social structure of the Roman house', PBSR 56 (1988), 43-97; 'Houses and households: sampling Pompeii and Herculaneum' in Marriage, Divorce and Children in Ancient Rome, ed. B. Rawson (Oxford 1991), 191-227; and 'Elites and trade in the Roman town' in City and Country in the Ancient World, ed. John Rich and A. Wallace-Hadrill (London 1991), 241-72. Acknowledgment is due to the authorities in the Soprintendenza at Pompeii, particularly to the present Superintendent Dr Baldassare Conticello, to Dr Antonio Varone, Director at Pompeii, and Dr Tomasina Budetta, Director at Herculaneum, for their willingness to facilitate my project; and to Mattia Buondonno and many other custodi for patience with a multitude of keys. I reiterate thanks for financial support which made the underlying fieldwork possible to Magdalene College, Cambridge, the research boards of the Universities of Leicester and now also of Reading, the British Academy, and the British School at Rome. My ideas have benefited greatly from discussion in seminars in Britain and Australia; particularly with Pim Allison, Jean-Paul Descoeudres, and Frank Sear. I have also profited from constructive comments on earlier drafts by Roger Ling, Dominic Perring, Paul Zanker, and the Editor. None of these should be held to blame for my views. 
Cicero's concern over the social and moral effects of the behaviour of the Roman elite stands in the mainstream of Roman moral thought. From the elder Cato onwards, articulate Romans voiced their anxieties about the upsurge of luxury. It was, of course, in the first place an elite phenomenon: the prime profiteers of war and provincial exploitation were the principes. But though the immediate concern of moralisers and legislators was doubtless for the disruption which luxury caused within the ruling class, they perceived the damage as affecting their whole society. Cicero is unambiguous: cupiditatibus principum et vitiis infici solet tota civitas. ${ }^{2}$

Authors of the early imperial period took up and reiterated the same thoughts. One context in which they are commonly met is in discussion of the censorial function of the emperor. Emperors were conscious of and exploited their perceived function as moral exemplars: Augustus wins the praise of Ovid for the example he set in destroying Vedius Pollio's luxury house in the heart of Rome (Fasti 6.642), Tiberius made a display of model parsimony in a state banquet (Suetonius, Tib. 34), while the frugal Vespasian is credited by Tacitus with putting an end by his personal example to the whole moral decline which reached its nadir under Nero (Annals 3.55). ${ }^{3}$ But though such passages share the assumption that luxury spreads in society through imitation, we may prefer to imagine that it was only the upper orders of wealthy senators and equestrians on whom the emperor could conceivably have any impact as role model.

Here the elder Pliny is an important witness. He was, as is notorious, obsessed with the impact of Roman successes and triumphs on society in spreading what he regarded as moral corruption, like the taste for pearls or for vessels of fluorspar. ${ }^{4}$ His model of Roman society is not without differentiation, and in one fine passage he sets clear limits to the social spread of a contagion. The skin disorder that broke out under Tiberius among the kissing classes who exchanged embraces at the

${ }^{2}$ Roman luxury as a social phenomenon still awaits proper treatment. There have been several recent accounts of censorial involvement with luxury: including G. Clemente, 'Le leggi sul lusso e la società romana', Societa Romana e Produzione Schiavistica, ed. A. Giardina and A. Schiavone, vol. iii (1981), 1-14; E. Slob, Luxuria: Regelgeving en maatregelen van censoren ten tijde van de Romeinse Republiek (1986); A. Astin, 'Regimen morum', JRS 78 (1988), 14-34; E. Baltrusch, Regimen Morum. Die Regelmentierung des Privatlebens der Senatoren und Ritter in der römischen Republik und frühen Kaiserzeit (1989). Broader and more sociological approaches are adumbrated in the doctoral dissertations of Deri P. Miles, Forbidden Pleasures: sumptuary laws and the ideology of moral decline in ancient Rome (London 1987), and Catharine Edwards, Transgression and Control: studies in ancient Roman immorality (Cambridge 1989), on both of whom I draw gratefully. See also E. La Rocca, 'Il lusso come espressione di potere', Le tranquille dimore degli Dei (1986), 3-35.

${ }^{3}$ Discussed in my Suetonius: the Scholar and his Caesars (1983), 177ff. See now P. Zanker, The Power of Images in the Age of Augustus (1988), 129: 'The emperor and his family set the standard in every aspect of life, from moral values to hairstyles. And this was true not only for the upper classes, but for the whole of society.' The importance of social diffusion of luxury is fully grasped by Zanker, who in a series of works points the way to further research. See esp. 'Die Villa als Vorbild des späten pompejanischen Wohngeschmacks', JdI 94 (1979), 460-523; also 'Zur Bildnisrepräsentation führender Männer in mittelitalischen und campanischen Städten...' in Les bourgeoisies municipales Italiennes aux IIe et Ier siècles av. F.-C. (1983), 251-66. His recent essay, Pompeji. Stadtbilder als Spiegel von Gesellschaft und Herrschaftsform (1988) is primarily concerned with the public buildings of the city, but see $23 \mathrm{f}$ on 'Wohngeschmack'.

${ }^{4}$ For Pliny's views on luxury see my discussion, 'Pliny the Elder and Man's Unnatural History', $G E^{2} R 37$ (1990), 80-96. 
salutatio only affected the proceres, the upper orders; it did not spread to the common people, the plebs, neither, he elaborates, to the servitia nor the plebes humilis aut media, that is to say to the slave class nor the poor nor to the rich outside the upper orders (26.3). But this limitation is specific to the spread of skin disorder. Elsewhere, in his far from coherent protests against the introduction of the gold ring as a status symbol to mark the equestrian order, he complains that legislation under Tiberius which attempted to restrict the wearing of gold rings after common tradesmen and barkeepers had used them to protect themselves from magistrates only encouraged the spread of the phenomenon among those of servile origin (33.32-3). Silver shoe buckles, paradoxically regarded as less trite and therefore more desirable than gold ones, became a luxury among women of plebeian status (luxu feminarum plebis), while embossed silver sword hilts attained fashion among common soldiers (33.152). Earrings formed of clusters of pearls called crotalia were the aspiration even of poor women (pauperes), and Pliny acknowledges the potency of 'luxury' in providing status markers, quoting the women as saying that 'a pearl was a woman's lictor in public' (9.115).

The model of society offered either by Cicero or Pliny is consistent. There was, and they felt ought to be, a divide between the upper orders, summi viri, principes, proceres or whatever, and the plebs. Naturally, luxury had its origin and most dramatic manifestations among the upper orders of senators and equestrians; but not the least alarming of its characteristics was the tendency to spread downwards, to Lucullus' freedman neighbour, to the barkeepers with gold rings, to the common women sporting what was doubtless no more than costume jewelry. But this model runs counter to a picture sometimes cherished by Roman historians. The vast riches squandered by the elite of the late Republic and early Empire, and the contrast with the undoubted squalor experienced by the poor, tempt us into polarising the culture of the elite and the culture of the masses. It is easy (and perhaps for us morally satisfying) to dramatise this contrast. ${ }^{5}$ But to fudge over the social diffusion of luxury is to miss something important both about the structure of Roman society, and about the way in which culture operated within society.

If Cicero and Pliny were right, the patterns at work in Roman society were by no means historically isolated or insignificant. In the course of indexing a collection of English seventeenth-century documents, Joan Thirsk was 'struck by the frequency of references to small consumer goods like brass cooking pans, cambric, gold and silver thread, hats, knives, lace, ribbons, ruffs, soap and tape'. Tudor moralists had regarded the introduction of these foreign novelties with horror; based often on cheap materials, these fashion goods involved the export of English bullion to pay for foreign labour. But home production soon came in, and what is startling is both the rapidity of spread of these initially elite fashions and the degree of social dissemination. Within two years of the first appearance of silk stockings on the legs of a courtier in 1575, they were offered for sale by a shop in Kirkby Lonsdale. Worsted proved a cheaper alternative to silk, and the stocking knitting industry expanded rapidly, catering not only for the middle but for the labouring

${ }^{5}$ Thus R. Macmullen, Roman Social Relations (1974), 88ff, stressing the 'verticality' of Roman social relationships, and minimising any 'middle' class. 
classes. Consumer goods reached a mass market. That was made possible by differentiation in the quality of goods produced. Low quality versions of elite fashions, often manufactured in the country, were sold to the humble. Such 'projects' in the seventeenth and eighteenth centuries created a mass market before the advent of the industrial revolution and multiplied opportunities for employment. They stimulated the economy without involving any change in work methods or the unit of production. Much in Thirsk's picture, the moralising, the rapidity of change of mores, is reminiscent of the Roman scene; and it points to the importance of examining the social diffusion of 'luxuries' and consumer goods. ${ }^{6}$

But before we accept the Ciceronian model, we require documentation. However emphatically he states that the morals of the elite penetrate the whole fabric of society (the passage quoted above continues with much more in the same vein), it is always possible that Cicero was sufficiently isolated from experience of the 'lower orders' to be a misleading witness to their lifestyle. The rich, successful freedman and his urge to 'ape' the aristocracy could not be missed: Trimalchio symbolises what was a longstanding Roman obsession. But what of the majority of poor freedmen, or the poor but honest ingenuus whom Juvenal's satirical tradition idealises? Not only do we require to know whether Cicero's picture is true; we need to know in precisely what degree it is true, how far through society the imitation of the elite extends. And we need to know how the picture develops over time, how far the supposed increase of luxury leads to greater social diffusion.

The material for answering these questions exists. Because luxury is part of material culture, archaeology can follow its traces. Moreover, the artefact as social symbol is one of the most prominent concerns of contemporary archaeology in other fields. ${ }^{7}$ Both materials and methods to construct a sociology of Roman luxury lie readily to hand.

One essential preliminary is to clarify our definition of 'luxury', since confusion can arise from its alternative senses. One sense, typical of usage in Roman authors, is essentially moralising. Luxury is what goes against the natural order, what is morally shocking and depraving in its effect. This definition we find unsympathetic, since from our own perspective what the Romans found depraving may be a normal part of life. Thus Friedländer pointed out how the spread of the refrigerator had rendered Roman protests against iced drinks absurd. ${ }^{8}$ There can be, that is to say, no absolute standards of luxury, only standards relative to the availability of given commodities within a society. For us, luxury is often explicitly relative: the 'de luxe' version is only recognisable as such by comparison with other 'standard' models.

But a relativist definition of luxury leads in its turn to difficulties. If luxury is in its nature relative, how can one ever speak of the social spread of any given luxury? For in becoming common, pearl earrings must cease to be regarded as luxurious at

${ }^{6}$ J. Thirsk, Economic Policy and Projects (1978), esp. 106-32 for social diversity and differentiation, and $12 \mathrm{ff}$ for moralising protest.

${ }^{7}$ E.g. Richard Bradley, The Social Foundations of Prehistoric Britain: themes and variations in the archaeology of power (1984); Ian Hodder, Symbols in Action. Ethnoarchaeological Studies of Material Cullure (1982).

${ }^{8}$ L. Friedländer, Roman Life and Manners, vol. ii (1908), $131 \mathrm{ff}$. 
all. To avoid this difficulty, it is essential to focus on luxury as a social process, rather than on the individual items which may be categorised as 'luxurious'. ${ }^{9}$ As a social process, luxury functions as the attempt to mark or assert a place within a network of social relationships by the display or consumption of material goods; in this process, the goods are valued in proportion to their relative inaccessibility outside the social circle that is employing them. In a competitive society, as fast as the leaders (Cicero's principes) seize new symbols to assert their power, like Lucullus and his villas, they will be emulated by those below. The wider the emulation spreads, the more debased the object of emulation becomes, and the greater the pressure grows on the leaders to innovate further, so distancing themselves from their imitators. ${ }^{10}$ In a stable society, the rate of innovation and diffusion will be low, so that the same 'luxuries' may mark the dominant class over a long period of time. But in an unstable and highly competitive society with strong elements of upward social mobility, diffusion will be wide and innovation rapid.

It is precisely a society of the latter sort that we witness in the Ciceronian and early imperial period. Whether the absolute standards of luxury attained by the Romans were high is irrelevant; nor does it matter to distinguish at what level specific goods or patterns of behaviour rate as 'luxuries'. The interesting question is to determine the extent and speed of diffusion of new status markers, and the rate of innovation at the top.

Numerous types of artefact reveal this process. We may think of the marvellous imitations of embossed silverware by the Arretine potteries, the scale of diffusion of Arretine ware, and the speed with which its production spreads to debased provincial versions. We may think of the spread of honorific statues and particularly the funerary commemorations that are so characteristic of the Roman empire - and here the most lamentable consequence of the disciplinary separation of history and archaeology has been the divorce between the study of funerary epigraphy and the study of the monuments which so eloquently comment on the status of the commemorand. ${ }^{11}$ Housing and decoration, which I here select for investigation, represent only one among many possibilities; but they represent an especially rich field for investigation both because of the importance which Romans attached to them as status symbols, and because of the systematic way in which the Vesuvian catastrophe has preserved a substantial body of evidence. If the evidence is limited to a given period and region, it is by chance the period at which Romans believed their own luxury to have reached a peak (or nadir) and the region of Italy which was most immediately affected by the fashions of the Roman rich. ${ }^{12}$

In a general sense, the evidence of Pompeii (not forgetting, as is easy,

${ }^{9}$ This account of luxury is indebted to M. Douglas and B. Isherwood, The World of Goods: towards an anthropology of consumption (1979) and N. Elias, The Court Society (trans. E. Jephcott 1983); for a historical review, E. Sekora, Luxury: the concept in western thought from Eden to Smollet (1977).

10 The model, and its impact on changing artistic fashions, is lucidly set out by Ian Morris, Burial and Ancient Society. The Rise of the Greek City-State (1987), 16f, drawing on D. Miller, Artefacts as Categories: a study of ceramic variability in central India (1985), 184ff.

${ }^{11}$ See now Henner v. Hesberg and P. Zanker (eds.), Römische Gräberstrassen. SelbstdarstellungStatus-Standard (Munich 1987).

${ }^{12} \mathrm{~J}$. H. D'Arms, Romans on the Bay of $\mathcal{N}$ aples (1970) remains basic on the social context. 
Herculaneum) has been endlessly exploited. One might argue that Pompeii has been only too dominant in setting our conceptions of the society of the early Empire: too urban and too Campanian. Hence, in part, the current attention to survey work which takes us out into the countryside. But ancient civilisation lies in a symbiosis of town and country, and it is premature to say that we understand Pompeii. It is at once the most studied and the least understood of sites. Universally familiar, its excavation and scholarship prove a nightmare of omissions and disasters. Each generation discovers with horror the extent to which information has been ignored, neglected, destroyed, and (the most wanton damage of all) left unreported and unpublished. Enormous efforts are being made now to repair the damage: but the sheer size of the site continues to defeat.

There are other obstacles, in the boundaries of disciplinary specialisation. Much excellent work has been done in the last generation by both classical archaeologists and social historians. Archaeological (and, more specifically, art historical) study has elaborated with great finesse the chronology of decorative fashions, while fighting shy of any systematic investigation of the implications for social history. ${ }^{13}$ Simultaneously, social historians have revealed much about the political, social and economic structures of the city through study of epigraphic documentation without making more than incidental use of strictly archaeological material. ${ }^{14}$ This is absurd, for the archaeological evidence is the best social document Pompeii has to offer.

All this means that there is still ample scope for using Vesuvian evidence to illuminate the social and cultural world of late Republic and early Empire. In particular, the archaeological evidence is susceptible to quantification: imperfect, without doubt, but at least to an extent that allows us to move beyond the impressionism which is bound to affect social history based purely on literary sources. In using here Pompeian evidence to attempt to control and quantify the picture sketched by Cicero, I do not underestimate and shall not conceal the methodological difficulties involved. Often the results of this investigation prove ambiguous and frustrating. Even so, there is enough to vindicate the Ciceronian picture of cultural diffusion, and to move towards understanding how and why it took place.

\footnotetext{
${ }^{13}$ Among art historians who have shown interest in the social aspect should be singled out Paul Zanker (above) and V. M. Strocka, esp. 'Pompejanische Nebenzimmer', in Neue Forschungen in Pompeji, ed. B. Andreac and H. Kyrieleis (1975), 101-14; Die Casa del Principe di Napoli (VI 15,7.8) (1984), esp. 49f. The works of Karl Schefold, especially Vergessenes Pompeji (1962) and Pompejanische Malerei, Sinn und Ideengeschichte (1952), are also concerned with the implications of decoration for society, though I find his model of how art reflects society unconvincing, cf. $\mathcal{J} S T 3$ (1983), 182.

${ }^{14}$ Minimal use of archaeological evidence is made in the (otherwise illuminating) studies of $\mathrm{J}$. Andreau, Les affaires de Monsieur Iucundus (Coll. Ec. Fr. Rome 19, 1974), P. Castrén, Ordo Populusque Pompeianus. Polity and Society in Roman Pompeii (Rome 1975); and recently W. Jongman, The Economy and Society of Pompeii (Amsterdam 1988). The main (glowing) exception is W. Jashemski, The Gardens of Pompeii, Herculaneum and the Villas destroyed by Vesuvius (New York 1979). Also valuable is the recent dissertation of V. Gassner, Die Kaufläden in Pompeii (Diss. Wien 178, 1986).
} 


\section{VITAL STATISTICS}

The first step should be towards some purely statistical calculations. This is something that has recently been tried by art historians concerned with the early modern period. The reduction of art to numbers appears crude in comparison to the refined judgements of traditional aesthetics. But it does serve a vital purpose in controlling the impressions that inevitably arise from an anecdotal approach. A study of seventeenth-century Delft by John Montias has shown that $66 \%$ of the householders possessed at least one painted canvas, and that the average number per household was eleven. ${ }^{15}$ It was even relatively common for artworks to hang in peasant households in the Netherlands. Dutch art may be a special case: but a study of Metz in the same period by Philip Benedict shows France not far behind. ${ }^{16}$ Again two-thirds of the households prove to have paintings, though the inventories on which this information is based are slightly skewed as a sample, and the proportion may consequently be reduced to $58 \%$. The mean is 5.5 canvasses per household, predominantly religious in Catholic houses, but not in Protestant ones. Social class affects the distribution: as against $90 \%$ of nobles with canvasses, $80 \%$ of the learned professions, slightly more of the merchants and officials, and nearly $55 \%$ of artisans, bourgeois and labourers had paintings. These numbers are by no means so banal and predictable as they might appear: before the investigation was made, it was confidently asserted that outside the Netherlands, paintings belonged exclusively to the crown, the nobility and the church. Post-industrial society brings rather different assumptions about the social diffusion of art. A survey of modern France cited by Zeldin indicated that in 1974 over half the population had no pictures or reproductions of art in their homes; about $20 \%$ had reproductions; $26 \%$ originals by amateurs; $23.5 \%$ posters; but a mere $8 \%$ originals by professional artists. ${ }^{17}$

No comparable figures are available for Pompeii, and two factors would make a precisely similar exercise impossible. In the first place, the 'art' of Pompeii is very different from the canvasses of the Netherlands or Metz. Lavish though it is, room-decoration is in a different league from easel-painting, and has as much in common with wallpaper as with canvas. More significantly, we lack the essential paper documentation from which Montias and Benedict were able to move. A corpus of inventories can supply both precise information about the social standing of the owners, and a full record of their possessions. Neither is attainable via the archaeological record. It is true that Della Corte's Case ed Abitanti di Pompei expended considerable ingenuity in pinpointing the social standing of houseowner after houseowner; and for Herculaneum, Maiuri was prepared not only to characterise socially the final owners, but their predecessors as well. Much of this has passed into general circulation in guide books, the 'Life at Pompeii' literature,

\footnotetext{
${ }^{15} \mathrm{~J}$. M. Montias, Artists and Artisans in Delft: A Socio-Economic Study of the Seventeenth Century (Princeton 1982).

${ }^{16} \mathrm{P}$. Benedict, 'Towards the comparative study of the popular market for art: the ownership of paintings in seventeenth-century Metz', Past and Present 109 (1985), 100-17.

${ }^{17}$ T. Zeldin, France 1848-1945. Taste and Corruption (1980), 98.
} 
and the oral tradition offered to visitors. But too little is reliable to be of use. ${ }^{18}$ Della Corte's use of graffiti and dipinti conjured names of owners out of thin air; while Maiuri's use of house decoration to infer the status of the owner would in the present context lead to circularity. It is pure assumption that the builder of a handsome tablinum such as that in house V.Il at Herculaneum will have been a 'patrician', or that crude patching of earthquake damage in the same house indicates its descent into the vulgar hands of a member of the 'ceto mercantile'. ${ }^{19}$

Certainly there are broad limits within which one can speculate with reasonable confidence about the standing of the inhabitants of any particular house. Nobody would doubt that the owner of the Casa del Menandro, with its spacious peristyle, handsome decoration, luxurious private baths, spectacular silver service, and extensive service quarters, would have been of the highest standing in local terms, and arguably on the level of the senatorial elite at Rome itself; and the epigraphic evidence may point to the consular family of the Poppaei Sabini. Or, at the other end of the scale, there is no mistaking the relative modesty of the likely inhabitants of the two upper flats in the flimsily constructed Casa a Graticcio in Herculaneum, which sometimes does duty as the 'typical' artisanal dwelling, though in fact neither flat is without decoration, charm, and a scatter of possessions improbable among the truly poor. But this anecdotal method throws too much weight on subjective impression and uncontrolled conjecture. Some sort of statistical control is essential. Just how big is a big house, how small a small one? What is the distribution of the various sizes? What architectural and decorative features, and what level of possessions indicate wealth or social standing? Can one distinguish wealth and rank-for instance the wealthy freedman from the local magistrate? What is the relationship between residential and non-residential (commercial, artisanal, horticultural, etc.) use of space, and what does the fact that part of a given house is used non-residentially indicate about the social and economic position of the inhabitants? All these are questions to which Maiuri (and many others) presuppose a series of answers, but to which no explicit or systematic discussion has been given.

In offering now an experiment in supplying some preliminary statistics, I do not delude myself that definitive figures are attainable. It is difficult to set up any statistical experiment without building in presuppositions in the form of the questions asked; there is a tendency to find precisely what you were originally looking for. At the same time, a statistical approach tends to stress factors which allow themselves to be reduced to numerical values: if the ground area of houses tends to feature largely in what follows, this is because it is a feature which lends

\footnotetext{
$1^{8}$ The methodological weaknesses of della Corte's work are well exposed by P. Castrén, Ordo Populusque Pompeianus, 31-3, cf. J. Andreau, 'Remarques sur la société pompéienne', Dial. Arch. 7 (1973), 213-54.

${ }^{19}$ So A. Maiuri, Ercolano. I nuovi Scavi (1927-1958) (1958), 247f. Maiuri's views are popularly accessible in his Pompeii (English trans. Novara 1960), esp. 72ff; scholarly argument rests on L'ultima fase edilizia di Pompei (L'Italia Romana. Campania Romana II, 1942), esp. 162ff. Like E. Lepore, 'Orientamenti per la storia sociale di Pompei', in Pompeiana. Raccolta di studi per il secondo centenario degli scavi di Pompei (Napoli 1950), 144-66 at 161f, I find his whole scheme of social classification 'troppo rigida'; I discuss this issue in detail in 'Elites and trade in the Roman town' (above n. 1).
} 
itself to measurement. Above all, there is a need for caution in the interpretation of statistics. In drawing inferences from a given pattern of figures, it is necessary to be alert both to statistical significance and to significance in the layman's sense. Apparently contrasting (or similar) patterns of figures may be the product of the random scatter of chance; statistical science offers methods of calculating mathematically (via such factors as standard deviation and standard error) the probability of a given set of figures resulting from mere chance. In the interests of intelligibility, I have on the whole avoided any calculation requiring mathematical sophistication. ${ }^{20}$ But even if one has established statistically significant patterns, it does not follow that inferences of any historical significance can be based on them. Rather than using statistical analysis to generate supposedly significant figures, I have thought it more fruitful to use them to test assumptions based on impressions and to throw up new questions.

Analysis of the whole of Pompeii is out of the question. In the first place, the labour would be immense, and its value would be undermined by the law of diminishing returns. ${ }^{21}$ In the second place, neither state of publication nor state of preservation would permit it. Pompeii is the victim of more than two centuries of archaeological experiment, and it is no surprise that so much of the site now stands ruinous or obstructed with a fairy-tale thicket of impenetrable scrub. The state of publication of what has been disinterred ('excavated' is largely a misnomer) is equally lamentable: only in exceptional periods have even sketchy reports been made public, and omissions continue to include virtually all new excavations since the Second World War. Small wonder if, in the face of obstacles of this magnitude, systematic study has been lacking.

Sampling offers a way around these problems, at least in part. So long as one can isolate a representative sample of a given population, it is superfluous to undertake the costly and usually (as in this case) impossible business of examining the whole population. But is it possible to take a truly representative sample of Pompeian houses? Most scholarly discussion of the site (and almost all discussion of wall-decoration) depends on taking a selection of houses scattered all over the site. Though at first sight this technique might seem to suggest random sampling, it is the opposite. Houses are chosen for their bearing on the matter discussed, and since this is mostly one or other aspect of fine decoration or architecture, the houses best known and most frequently discussed are inevitably a special set, which is only too likely to coincide with the better-off inhabitants. A 'small' house seen from this perspective is likely to tend toward the average overall. ${ }^{22}$

\footnotetext{
${ }^{20} \mathrm{~A}$ helpful introduction for non-mathematicians is D. Rowntree, Statistics without Tears (1981). I am grateful to colleagues in the Department of Applied Statistics at Reading for advice and discussion; despite the possibility of using more sophisticated mathematical procedures to analyse my material, I have felt the potential advantages to be outweighed by the danger of confusing myself and my readers.

${ }^{21}$ On the principles of sampling, cf. the salutary remarks of $\mathrm{K}$. Hopkins, Death and Renewal (Cambridge 1983), 130ff.

${ }^{22}$ There has been surprisingly little study of smaller houses, despite the example set by J. Packer, 'Lower and middle class housing in Pompeii: a preliminary survey', Neue Forschungen in Pompeji, 133-42; see now Gassner op. cit. (n. 14). Note the useful insights of A. Hoffmann, 'L'architettura' in Pompei 79. Raccolta di studi... ed. F. Zevi (1984), 97ff.
} 
By chosing a group of adjacent blocks (so-called 'insulae') it is in fact possible to get a remarkably good cross-section of the range of Pompeian houses. That this is so is a result of the strikingly mixed distribution of houses in Pompeii (see below, III). For this purpose, I have chosen three different samples for comparison. The first is a group of seven adjacent blocks, comprising some 78 houses, in Regio I. Excavated in the course of this century, mostly by Maiuri, they represent easily the best preserved major section of the city. This is essential, for the houses which have suffered most neglect are those which are poorest in the material sense. Any gulf between rich and poor will be much exaggerated by the tendency to preserve and even improve the finest houses, while the plaster and masonry of the poorest is left to disintegrate. But while relatively well preserved, this group of blocks is very unevenly published and studied. The first publications of Insulae 6, 7 and 10 must count among the most thorough to date in Pompeii; ${ }^{23}$ Insula 10 has the additional advantage of being the focus of the very thorough British survey. ${ }^{24}$ On the other hand, Insulae 8, 9, 11 and 12 were excavated in the early $50 \mathrm{~s}$ in a great hurry, and remain without excavation reports, though individual houses have been examined by various scholars. ${ }^{25}$

As a control I have taken a group of eight blocks, comprising some 104 houses, in Regio VI. Excavated in the course of the nineteenth (and very early twentieth) centuries, the preservation of this area is very uneven, and if the area sometimes enjoys the reputation of having been the 'smart' quarter, this is partly due to the virtual obliteration of all but the show houses. Again the publication is very uneven: the more westerly blocks predate the days of archaeological reporting, but the easterly blocks were reported, particularly by Sogliano and August Mau, one of the giants of Pompeian scholarship. ${ }^{26}$ As a second control I turned to the central group of four insulae (52 houses) in Herculaneum. This has several attractions. By affording a glimpse of a different town it helps to reveal in what ways Pompeii itself may have been atypical, even if in two neighbouring towns the differences are in any case not likely to have been marked. Its excavation, like that of Regio I in Pompeii, is relatively recent, and it is, if anything, rather better preserved. It has the particular advantage of preserving much of the upper floors which also existed at Pompeii, but have been largely lost. Finally, it is fully published in the lavish volume by Maiuri, though here as elsewhere he eschewed the humdrum details

\footnotetext{
${ }^{23}$ Published by Maiuri, $\mathcal{N} S_{c} 1927,3-83$; 1929, 354-438; O. Elia, $\mathcal{N} S_{c}$ 1934, 265-344.

${ }^{24}$ R. Ling, 'The insula of the Menander at Pompeii: a preliminary report', Ant.Journ. 62 (1983), $34-57$.

${ }^{25}$ According to the directorate of Pompeii, steps are now being taken to repair these much lamented omissions. But despite descriptions of individual houses (esp. M. de Vos, Med.Ned.Inst.Rom. 1976, 37-75 on I 9.13; ibid. 1975, 47-85 on I 11.12 and 14; Jashemski, Archaeology 20 (1967), 37-44 on I 11.11), there can be no substitute for a true excavation report. Note also forthcoming volumes on I 6.15, I 7.1 and I 11.6-7 in the 'Häuser in Pompeji' series (Strocka, Rivista di Studi Pompeiani 2 (1988) $246 \mathrm{f}$.

${ }^{26}$ Insulae 15 and 16 are particularly well reported, by A. Sogliano in $\mathcal{N S C}$ 1897, 19-42; 1906, 374-83; 1907, 548-93; 1908, passim, and by Mau, Röm.Mitt. 1898, 3-54 etc.
} 
which are normal in archaeological reporting, including virtually any mention of the finds. ${ }^{27}$

In gathering data, I have made a detailed study of all the houses in the Regio I and Herculaneum samples, and a partial study in the (far less rewarding) Regio VI. However, in order to avoid distortions resulting from either bias or ignorance, I have only made use of my data where confirmed by published sources. Three major recent works have been essential in supplying data. The first is Hans Eschebach's Die städtebauliche Entwicklung Pompejis (1970). As the first attempt to list systematically all excavated houses, and above all to give a detailed overall plan, this has been of constant help to students of Pompeii for fifteen years. However, as detailed inspection of Regio I soon revealed, it is highly unreliable in point of detail. Mapping errors even afflict houses published accurately in Notizie degli Scavi; but the sheer magnitude of the task bravely undertaken by Eschebach is adequate excuse. His work has been in part superseded by a much more ambitious and thorough project, the series of volumes of the Corpus Topographicum Pompeianum. Though much of this project suffers from overkill of inessential information, the new maps of vol. III, both the overall site plan, and particularly the block by block plans at 1:500 scale, are admirable, and correct every error in Eschebach which I have observed. ${ }^{28}$ While Eschebach and the CTP provide information on ground plans, decorative features are now comprehensively surveyed in the official catalogue to the photographic archive, Pitture e Pavimenti di Pompei, by De Vos and others. ${ }^{29}$ This seemingly impenetrable list of decorative features, house by house, room by room, wall by wall, offers an excellent tool for statistical purposes. It satisfies one important requirement for statistics in its comprehensiveness; and offers a clear and accurate record of the period and degree of elaboration of all wall, ceiling and floor decoration either surviving or once photographed. It would be of great value if the project were extended to Herculaneum.

Finally, the recent publication, after the completion of my own calculations, of a semi-official inventory and computer-based analysis of Pompeii has a direct bearing on my own project. The two volumes of Pompei. L'informatica al servizio di una città antica (1988, first available 1989) constitute a major step towards rectifying previous neglect of basic statistics. This offers a new official cartography of the site; unfortunately the presentation is much inferior to that of the CTP and, where it differs in point of detail, suggests more hurried and less reliable surveying. In addition it offers a new directory identifying the houses region by region according to usage. Here, too, it is less than fully reliable, for the identifications of usage are

${ }^{27}$ The finds are now in course of publication, in the series Soprintendenza Archeologica di Pompei Cataloghi, starting with L. A. Scatozza Höricht, I vetri romani di Ercolano (1986) and M. Conticello De Spagnolis and E. De Carolis, Le lucerne di bronzo di Ercolano e Pompei (1988), and with a projected volume on jewelry by Scatozza Höricht. Welcome though this is, this form of publication succeeds in maximising the divorce of finds from the context of discovery, and so in minimising their archacological and historical utility.

${ }^{28}$ Corpus Topographicum Pompeianum, ed. H. Van der Poel, IIIA (1987). Eschebach is sharply criticised, e.g. on pp. 12, 14.

${ }^{29}$ Repertorio delle Fotografie del Gabinetto Fotografico Nazionale. Pitture e Pavimenti di Pompei, ed. I. Bragantini, M. de Vos, F. P. Badoni et al.; Parte I (Regioni I, II, III, 1981); II (Regioni V, VI, 1983); III (Regioni VII, VIII, IX, 1986). 
conventional, not the result of new research; and while it performs a useful service in identifying the principal entrance of each complex with several entrances and multiple usage, the subsequent analysis wholly confuses the issue by treating each door as a separate unit. Its major drawback, however, as a contribution to statistical analysis of the site, is the complete absence of measurements. To treat every unit as equal, irrespective of its size, is to invite misunderstanding, as the barcharts and piecharts analysing usage of space soon reveal. Ambitious projects to establish at Pompeii a computer centre with a database that rectifies these shortcomings are now in progress, and it is to be hoped that it will soon be possible to control and move beyond my own experimental and tentative calculations.

I move from a database covering some 234 houses in the three sample areas. A range of information can be assembled for each house.

1. Size. How large is the house (ground area)? How many rooms does the ground floor comprise? How much of the ground area is built over, how much open?

2. Function. What proportion is residential, what proportion serves some economic function, commercial/artisanal, horticultural, or other?

3. Architecture. Does the house have an impluviate atrium? Does it have a colonnaded garden ('peristyle'), and if so of what size and with how many colonnades?

4. Decoration. How many rooms have wall decoration, and in which of the four standard styles? How many have notable decorative features, especially mythological paintings and mosaic floors?

Most of these questions can be answered with a reasonable degree of reliability for most of the houses involved. Ideally a fifth category should be added, covering the nature and richness of the finds (silver, carved marble or bronze, coins, utensils in bronze, glass, terracotta and so on), but the state of publication and state of scholarship makes this aim frustratingly unattainable (see VII below).

In the following sections, I shall look at each of these aspects in turn, exploring both the rationale for and limitations to these questions, and examining the implications of the results that emerge.

\section{SIZES AND DISTRIBUTION}

In general terms, one may expect the size of a house to be a measure of the wealth and status of its inhabitants, and simultaneously of the number of its inhabitants. For the Romans in particular size is likely to be of significance: the laxitas of the spreading houses of the rich attracted persistent criticism from the moralisers of the period, ${ }^{30}$ and we have Vitruvius $(6.5 .1-2)$ to remind us both that public figures

\footnotetext{
${ }^{30}$ Cic. de Off. i. 139, cf. de Domo 116; Sallust Cat. 12.3, 'villas ... in urbium modum aedificatas'; Seneca de Ben. 7.10.5, 'aedificia privata laxitatem urbium magnarum vincentia', cf. Ep. 114.9; Suetonius Aug. 72.1; Cal. 37.2. Cf. D'Arms, Romans on the Bay of Naples, 40.
} 
needed ample reception space, and that the humble did not. House size constituted not merely an indirect reflection, but an explicit statement, of social rank; the municipal law of Tarentum actually required any decurion of the city to possess a house there with a roof of a minimum 1,500 tiles, ${ }^{31}$ and one would anticipate similar expectations at Pompeii. The prevalence and scale of slave-owning in the period is another vital factor: since slaves were at once a product and a symbol of wealth, the houses of the wealthy are likely to have been simultaneously larger and more populous.

The first step must be to measure the ground area of each house. No published figures are available, but the much improved cartography (see above) makes possible measurements adequate for the purpose, i.e. normally to within $5 \%$ either way. Various limitations on the value of this exercise are worth noting. The first is a difficulty in the definition of a 'house'. In the majority of cases the matter is unambiguous: it is a unit of habitation (which may also be used for non-residential purposes) which is inaccessible from any other unit except via the public street. But there are other units, particularly small shops and large horticultural areas, which may well have been uninhabited. We cannot be sure. To exclude them would be arbitrary; we must therefore stretch the definition of 'house' ('unit' would be a more neutral, but pedantic, term) to include these, but remain conscious of the possibility that any unit with a predominantly non-residential function may not have been inhabited. Similarly, there were almost certainly some houses which by A.D. 79 were uninhabited because abandoned. Only careful examination of the finds can establish abandonment with reliability, and one of the major frustrations of the inadequate publication of a large proportion of these houses is that the necessary information is not available. The possibility that any given unit may have been unoccupied in A.D. 79 must be borne in mind. ${ }^{32}$

In some cases it is unclear where to draw the boundaries of a 'house'. Many units are evidently formed either by the combination of previously separate units, or alternatively by splitting up what was previously a single unit. The commonest case of the latter is where a shop has been opened up in what was a front room in a house: traces of this process are visible in blocked-off doors (one of the merits of the CTP map is to mark such 'ostia murata ab antiquis' systematically). In these cases it is obviously right to treat a shop, if inaccessible from the house, as a separate unit. In a statistical comparison, it is necessary to limit the enquiry to one point in time (in theory, 24/5 August 79), though all the time we are reminded that Pompeii was an organic entity in a state of constant flux, each unit the product of changes in the past, and in turn liable to generate changes in the future. ${ }^{33}$

${ }^{31}$ Lex Municipii Tarenti, CIL I, $2^{2} 590=I L S 6089=$ FIRA i.18, at lines 26ff.

${ }^{32}$ Notable examples of deserted houses include I 6.13 (cf. $\mathcal{N S C} 1929,430$ ), I 9.8/9/10 (cf. CTP IIIA, 16). Evidence of earthquake damage and incomplete recovery in A.D. 79 is widespread, cf. Maiuri, L'ultima fase edilizia, 216f. The importance of deserted houses is brought out in C. Phythian-Adams, The Desolation of a City. Coventry and the Urban Crisis of the Late Middle Ages (1979), a case where a city in steep economic decline had as many as $25 \%$ of its houses empty.

${ }^{33}$ Maiuri, L'ultima fase edilizia, esp. 161ff. Yet even without earthquake damage, constant adaptation of housing stock is to be expected; cf. the substantial changes now revealed in insula I 20 , S. Nappo, Rivista di Studi Pompeiani 2 (1988), $186 \mathrm{ff}$. 
The hardest cases are those in which two houses are linked to each other by an interconnecting door, and yet potentially function as separate units. Here it has been necessary to exercise discretion. Thus I 12.1-2 is formed of two units of the same size; one is a bakery, complete with mills, mixing-room, oven and stables, while the other is a residential unit. The interconnecting doors show that this functioned as a single unit, and it has been treated as such; but naturally the fact that half is a bakery will affect our expectations of signs of wealth in the residential quarter. On the other hand, the complex at I 7.10/11/12/19 (the Casa del Efebo), while formed from up to four previous units, falls distinctly into two halves, each with a separate main entrance (at 10 and 19), atrium and garden. Connected at the bottom of their respective gardens by a small door and a flight of steps, they must in A.D. 79 have formed a single unit of ownership. It is hard to envisage their operation except as two separate units of habitation, and I have followed CTP and others in treating them as separate 'houses'. But in reality the division goes further. Entrances 10 and 11 are both apparently main doors, and inside the house between them were found traces of a heavy wooden partition with locks. ${ }^{34}$ The whole area then, is quite likely to have functioned as three separate units; but since features like wooden partitions do not appear on the ground plans, such subdivisions are obscured. In interpreting the statistics, it is necessary to allow for the possibility of multiple residences within units like this. At the very least, they serve to remind us that units of habitation or usage are not the same as units of ownership. Ownership is much harder (and usually impossible) to trace archaeologically; we must often be dealing with rented accommodation and the like.

The second limitation on the value of measuring ground area is that it ignores the vertical dimension. Herculaneum offers a vivid reminder of the frequency of upper floors, and though these do not generally survive in Pompeii, architectural traces, particularly stairs, show that the same was the case there. Measurement of ground floor alone is not equivalent to total living space, though it may act as an indicator. For some purposes, this limitation is of great significance-for instance in any calculation of population, it would be foolish to lay weight on the number of bedrooms downstairs. Again, the absence of decoration on the ground floor does not prove its absence from the house as a whole, and, as we shall see, it is by no means unlikely that undecorated shops had decorated living quarters above. But the limitation does not matter where one is comparing like with like. The ground area of a house dictates its maximum possible size, and a smaller ground area cannot sustain a larger house so long as they are of the same constructional type. To compare the ground area of a Pompeian house to that of an Ostian multi-storey insula would be highly misleading, and for this reason I have deliberately omitted from the sample the Palaestra block at Herculaneum, the one case of the type of multi-storey brick and concrete block. ${ }^{35}$ As with the problems of defining a 'house', this limitation will have an important bearing on our interpretation of any

${ }^{34}$ NSc 1927, 38-9.

${ }^{35}$ The population of this type of accommodation has been much more thoroughly studied: by $\mathrm{J}$. Packer, The Insulae of Imperial Ostia (MAAR 31, 1971); G. Hermansen, Ostia. Aspects of Roman City Life (Univ. of Alberta, 1982), 17ff; J. C. Boersma, Amoenissima Civitas: Block V.ii at Ostia (1985), questioning the basis of Packer's population estimates (cf. R. Ling, $7 R S 63$ (1973), 279-81). 
statistics, but it does not mean that the data is less worth gathering and analysing.

Let us, then, first consider the distribution of house sizes, measured on ground area alone. Anyone visiting the sites or even consulting the map must be struck by the extreme variation in sizes and the intricate jigsaw they form, an interlocking pattern of large and small units within virtually every block.

Figure 1 attempts to represent the range of plot sizes and their distribution by grouping them into successive bands of $100 \mathrm{~m}^{2}$ up to $1000 \mathrm{~m}^{2}$, and larger bands thereafter. Not surprisingly, it emerges that the smaller the size, the commoner it is, and if the largest group, that of houses under $100 \mathrm{~m}^{2}$, is subdivided, those under 50 $\mathrm{m}^{2}$ are commoner than those above. What is more impressive is the result of comparison of the three component samples (Fig. 2). They are remarkably consistent, both in the closeness of the mean house size within each sample (Regio I, $266 \mathrm{~m}^{2}$; Regio VI, $289 \mathrm{~m}^{2}$; Herculaneum, $241 \mathrm{~m}^{2}$; overall, $27 \mathrm{l} \mathrm{m}^{2}$ ) and for the broadly similar distribution of different sizes. In itself, this consistency suggests the potential value of the sampling method. It confirms that a sample of as few as 52 houses in adjacent blocks will give a reasonable cross-section of house sizes at least, and that this cross-section is not likely to be radically different in different areas of the city, or even within two neighbouring Campanian towns. It also suggests that our understanding of the distribution of house sizes in these towns would not improve greatly if we (say) doubled the size of the sample. Fig. 3 compares the distribution of house sizes in the total sample of 234 houses with that of the Regio VI sample (104 houses); the close similarity of the patterns shows how little is changed by doubling the sample size.

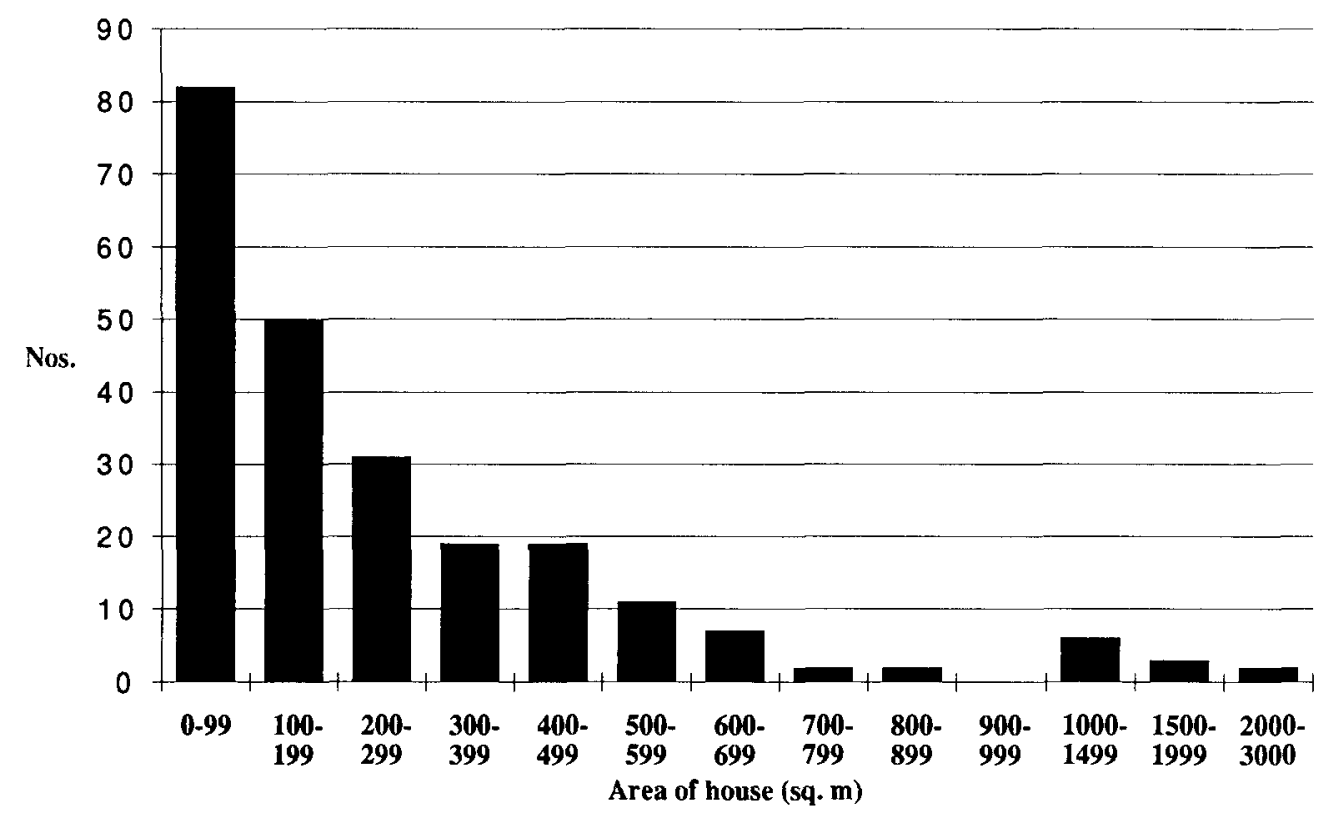

FIG. 1. Distribution of houses in Pompeii and Herculaneum samples (total numbers). 


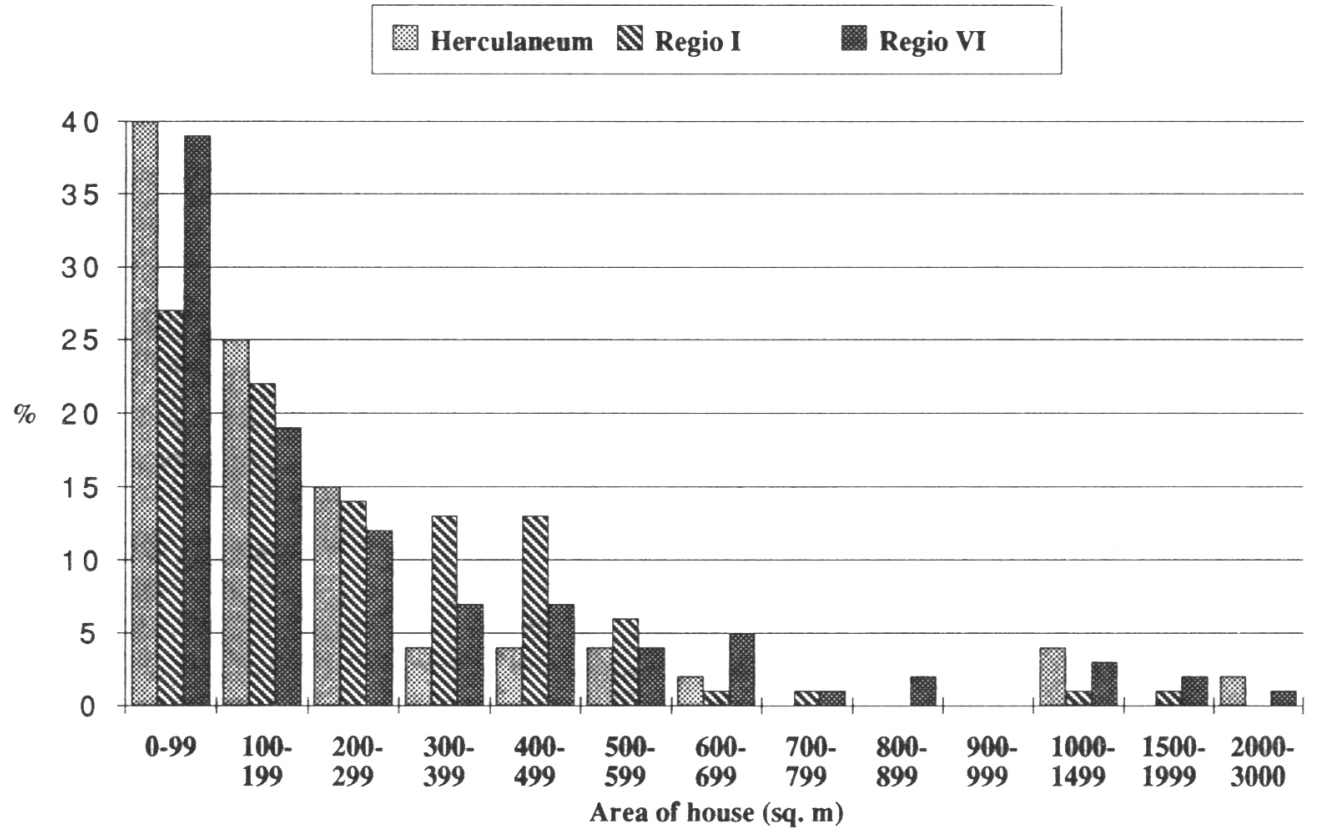

FIG. 2. Distribution of houses: Pompeii and Herculaneum samples compared.

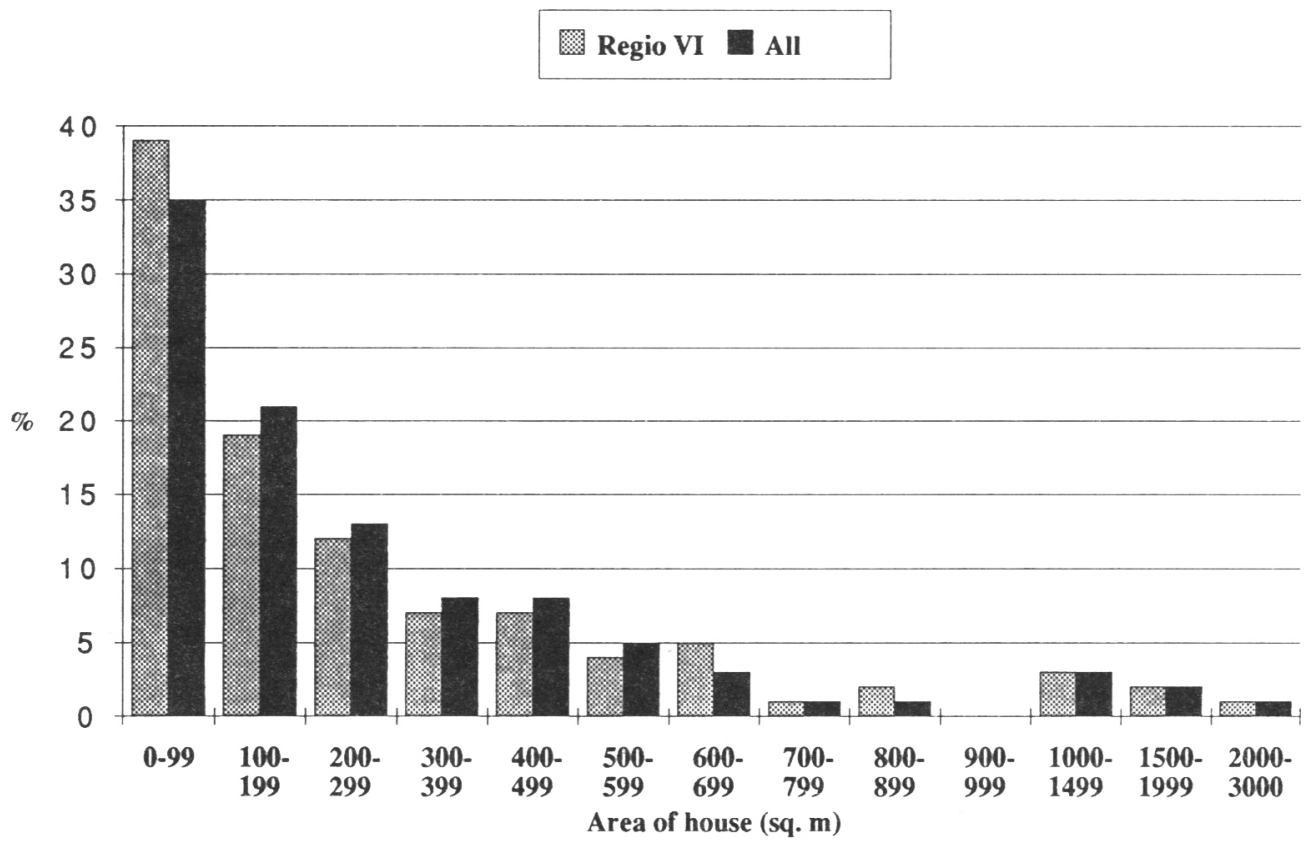

FIG. 3. Distribution of houses: Regio VI and total sample compared. 
TABLE 1

Averages for area, rooms and open space (total sample).

\begin{tabular}{lccccc}
\hline $\begin{array}{l}\text { Size } \\
\text { sq.m }\end{array}$ & $\mathcal{N}=$ & $\begin{array}{c}\text { Avg area } \\
\text { sq.m }\end{array}$ & $\begin{array}{c}\text { Avg open } \\
\text { area sq.m }\end{array}$ & $\begin{array}{c}\text { Avg rooms } \\
\text { per house }\end{array}$ & $\begin{array}{c}\text { Density } \\
\text { (rooms:area) }\end{array}$ \\
\hline $10-99$ & 82 & 38 & 0 & 2 & $1: 19$ \\
$100-199$ & 50 & 145 & 2 & 6 & $1: 25$ \\
$200-299$ & 31 & 240 & 22 & 9 & $1: 27$ \\
$300-399$ & 19 & 337 & 73 & 9 & $1: 38$ \\
$400-499$ & 19 & 435 & 87 & 12 & $1: 36$ \\
$500-599$ & 11 & 527 & 85 & 13 & $1: 41$ \\
$600-699$ & 7 & 665 & 103 & 17 & $1: 39$ \\
$700-799$ & 2 & 775 & 134 & 18 & $1: 43$ \\
$800-899$ & 2 & 825 & 165 & 21 & $1: 39$ \\
$900-999$ & 0 & - & - & - & - \\
$1000-1499$ & 6 & 1152 & 179 & 20 & $1: 58$ \\
$1500-1999$ & 3 & 1677 & 215 & 32 & $1: 52$ \\
$2000-2999$ & 2 & 2658 & 692 & 33 & $1: 81$ \\
\hline
\end{tabular}

This is far from suggesting some sort of total homogeneity, let alone an identical pattern in all Roman towns. Of course there are marked variations in distribution from block to block, and even in area to area. ${ }^{36}$ Thus it is notable that shops cluster along the frontages of main streets. Since each of the three samples includes at least one major public thoroughfare, the smallest units, formed by shops, are well represented in each sample. But there are blocks, like VI 9, 11 and 15, which have few small units, and others, like VI 16 on the intersection of two main roads, with disproportionately many. The largest houses, too, may tend to cluster locally: Herculaneum offers an unmistakable cluster of very grand houses along the sea-wall, doubtless attracted by the fine view of the bay, while in Regio VI of Pompeii there is something of a cluster of larger houses along the Via di Mercurio leading directly to the head of the Forum. It is also possible to detect local groupings of commercial and horticultural plots in Regio I (see below). But even these minor local variations are not enough to disrupt the underlying pattern of mixture of large and small. There is no hint of the sort of zoning that typifies the post-industrial city and which has attracted so much attention among urban geographers. ${ }^{37}$

Other basic measurements may help to refine the picture of the range of housing suggested by ground area alone. One traditional and convenient measure of house size is number of rooms. The value of this measure is obviously limited by our inability to quantify missing upper rooms, but so long as it is remembered that these figures are not equivalent to a total room count, they are of great assistance in comparing like with like. A 'room' is as elusive to define as a 'house'. Standard plans carry room numerations, but many of the numbers refer to public circulation areas rather than rooms (e.g. fauces, atrium, alae, passages, or peristyle gardens). I have excluded such areas from the count, as also areas too small to rate as rooms

${ }^{36}$ H. Eschebach, Neue Forschungen in Pompeji, 331 briefly characterises some of the regional contrasts of Pompeii; cf. now the much fuller analysis of G. F. La Torre (below n. 45).

${ }^{37}$ Most recently discussed by Jongman, Economy and Society, 108-12. 
(especially latrines and small cupboards/storerooms). Generally I take a room to be an enclosed area accessible through its own door, though even with this restriction, there are often ambiguities, and my figures must be taken as approximate, establishing an order of magnitude (Table 1).

Since a room count does not adequately reflect the importance of areas like peristyle gardens, I have added a further figure for the ground area of open space within the house, whether its use was utilitarian or recreational. It is a notable feature of the larger houses of both towns that they include a great deal more open space, not only absolutely, but also proportionately, than do the smaller houses. It is also the case that larger houses have more large rooms; indeed, the largest room in a house as grand as the Casa del Menandro (I 10.4) by itself covers an area equivalent to the total area of as many as a third of the houses in the sample. One way of expressing the more lavish use of space in the larger houses is to divide the total ground area by the number of rooms. The resulting figures for density of rooms : area show a fairly consistent easing of ratios, from the cramped 1 room per $19 \mathrm{~m}^{2}$ of the smallest houses to the spacious 1 per $81 \mathrm{~m}^{2}$ of the largest.

The disadvantage of presenting the data in this way, by equal bands, is that the largest houses are split into too many categories with too few members, while the smallest band contains too many and so conceals large contrasts. A more intelligible procedure is to split the whole sample into quartiles according to size (Table 2: note that the quartiles are not exactly equal, since houses of the same area may bridge the exact quartile point).

TABLE 2

Area and rooms by quartile.

\begin{tabular}{lcccccc}
\hline Quartile & $\mathcal{N}=$ & $\begin{array}{c}\text { Area } \\
\text { sq.m }\end{array}$ & $\begin{array}{c}\text { Avg area } \\
\text { sq.m }\end{array}$ & $\begin{array}{c}\text { Avg open } \\
\text { area sq. } m\end{array}$ & $\begin{array}{c}\text { Avg rooms } \\
\text { per house }\end{array}$ & $\begin{array}{c}\text { Density } \\
\text { (rooms:area) }\end{array}$ \\
\hline 1 & 58 & $10-45$ & 25 & 0 & 1.4 & $1: 18$ \\
2 & 61 & $50-170$ & 108 & 1 & 4.7 & $1: 23$ \\
3 & 57 & $175-345$ & 246 & 16 & 8.4 & $1: 29$ \\
4 & 58 & $350-3000$ & 714 & 104 & 16.4 & $1: 45$ \\
\hline
\end{tabular}

The four groups represent substantial contrasts, as we shall see, in terms of function, architectural features and wealth of decoration. Though by this approach we lose in terms of fine precision, it is of great benefit for statistical reliability to have a larger number in each group, and from this point onwards the data will be presented in this form. It will be clear from comparison of this with the previous table that the greatest range of variation lies in the top quartile, which ranges from middling sized houses of no high pretensions to palatial establishments ten times their size. The bottom quartile represents almost exclusively single room shops, occasionally with a small back room. Between the top and bottom quartiles lie a progression of small to middling houses, the simplest with no more than a front and back room round a central circulation area, the larger achieving the classic pattern of atrium house with small peristyle to the rear. 
That, in broad terms, we are dealing with a progression of wealth and status between these quartiles must be evident, though it will be equally clear that not every large house necessarily contained, or even belonged to, wealthy people, and that not every small shop belonged to, or was even inhabited by, poor people. The distribution of house sizes will be a very different matter from the distribution of wealth within society, as indeed from the distribution of population. The inferences we can draw about population and household structure are a complex issue which I discuss in detail elsewhere. ${ }^{38}$ Here it is enough to emphasise the obvious point that the bottom quartile of houses judged by size cannot conceivably have contained all the bottom quartile of the population. Nor is it likely that the poorest lived exclusively in the smaller houses; they may equally have lived in the largest houses, as slaves, dependants, tenants and lodgers of the rich.

In the context of the examination of the spread of luxury, the interest lies in the houses themselves. The largest houses offered the greatest potential for status display, and if we were dealing with a society in which only a narrow elite deployed such status symbols, we would not expect many traces of these symbols outside the largest houses. In fact, as we shall see, the very largest houses do indeed give the richest display; yet ripples of luxury spread outwards and downwards to all but the smallest houses. The interest lies in tracing the progression of these ripples, both over different grades of house and over time.

Before examining these signs of luxury, however, it is important to take into account a fundamental contrast in usage of space. A large open area might serve to enhance considerably the standing of a house, if surrounded by gracious porticoes, planted with specimen trees and flowering shrubs, and decorated with statuary and plashing fountains. On the other hand, it might serve the purely practical function of a hortus, as a vineyard, for the commercial cultivation of flowers, or simply for raising vegetables for the table. ${ }^{39}$ Equally, the rooms and other areas of the house might serve either for gracious living and reception or for practical purposes such as for manufacture and processing, for sale of goods, or simply for storage. The usage of space has an obvious bearing on the analysis of luxury in housing, not least because the Romans themselves regarded utilitarian usage and luxury as alternatives.

Thus the lawyers drew a sharp distinction between expenditures on a house that were useful and those that were merely for pleasure (impensae utiles and voluptariae). Useful expenditures were those that improved the value of a property, such as adding a bakery, a shop (taberna) or a storeroom (horreum); those for pleasure were such that improved the decoration but not the returns of the property, such as making gardens (viridaria) and fountains, adding marble veneers (incrustationes), pavements (loricationes) and wall-paintings (picturae). ${ }^{40}$ The lawyers are here strictly concerned with property as an economic asset, so speak of the utilitarian improvements in positive terms, in contrast to the decorative improvements. Thus

${ }^{38} \mathbf{I}$ discuss the bearing of these statistics on population in detail in 'Houses and households' (above n. 1).

${ }^{39}$ The contrasts are brought out well by Jashemski, Gardens of Pompeii (cited n. 14).

${ }^{40}$ Dig. 5.3.39.1; 25.1.6; 50.16.79. 
they are not concerned with the social enhancement of a property. They do, however, as we shall see, acknowledge elsewhere that 'voluptuary' enhancements were both expensive in themselves and highly desirable, though the moralising rejection of luxury may lead them to take a harsh view of the matter. ${ }^{41}$ The next step, then, is to examine the contrast between (in our own terms) residential and non-residential use of space.

\section{RESIDENTIAL AND NON-RESIDENTIAL SPACE}

It is not unreasonable to assume that two houses of the same size and type and with the same number of rooms will tend to contain the same number of inhabitants of approximately the same degree of wealth. But we might indeed be surprised if a bakery or fullery were on a par with a purely residential house of the same dimensions. How will this affect our calculations?

This is, as it happens, an area in which some helpful statistical work has already been undertaken. Eschebach was concerned with charting the different categories of usage of space, and his colour-coded plan offers a vivid picture of the importance and diffusion of the non-residential across the 'houses' of Pompeii. ${ }^{42}$ Jashemski's brilliant excavations of soil-surface and roots in a variety of gardens revealed the (hitherto unsuspected) importance of horticulture within the walls, and she was well aware of the social and economic significance of her findings. ${ }^{43} \mathrm{~A}$ more thorough-going attempt at a statistical approach has been by Raper. ${ }^{44}$ Using models of analysis derived from urban geographers, he divided Pompeii into a grid of squares, and compared the distribution of different types of usage across the grid. The pattern that emerged confirms the visual impression derived from Eschebach's plan: of a confused jumble of shops, workshops, crafts, horticultural plots and houses across the whole city, with no real attempt at segregation or concentration beyond the tendency of shops to line main roads, and horticulture to cluster on the margins, at the furthest distance from the Forum. Broadly similar findings emerge from the analyses of the contributors to the new Pompei. L'informatica volumes: La Torre in particular shows that though there are contrasts to be drawn region to region, the overwhelming pattern is of a mixed distribution of the various types of commercial and artisanal activity, whether of bakers, fullers, taverns and inns or even (if credibility stretches this far) brothels in among the residential areas of the city. ${ }^{45}$

For present purposes, it is not enough to observe the geographical scatter of non-residential activity. It is necessary to have more precise information about the relationship between different types of use of space, and about the inferences we are

${ }^{4} \mathrm{Cf}$. below, section VI.

${ }^{4}$ Eschebach, Neue Forschungen in Pompeji, $331 \mathrm{f}$.

${ }^{4} 3 \mathrm{Jashemski}$, Gardens of Pompeii, 24 offers a histogram of land-use.

${ }^{4}$ R. A. Raper, 'The analysis of the urban structure of Pompeii...' in Spatial Archaeology, ed. D. L. Clarke (1977), 189-221.

${ }^{45}$ G. F. La Torre, 'Gli impianti commerciali ed artigianali nel tessuto urbano di Pompei', in Pompei. L'informatica (1988), 75-102, a valuable discussion. 
entitled to make when we find evidence of non-residential activity. Here we are hampered by the limitations of what archaeology can tell us, and above all by the imprecision of the archaeological reporting. Three broad categories can be distinguished. Shops, with their wide openings on the road, are easy enough to distinguish on architectural grounds, though they require more careful excavation and reporting of the finds than has often been the case. These tabernae cover a range of activities, from retail to production and retail; many are for the sale of food and drink. ${ }^{46}$ Secondly, there are the open areas for horticulture; these, too, are easily recognised on a ground plan, though it requires the techniques of excavation pioneered by Jashemski to distinguish viticulture, floriculture, market-gardening etc. The third category, of various trades and types of production dubiously labelled as 'industrial', is both more diverse, and hard to identify and quantify. Some establishments, such as those of bakers, fullers, dyers, metalworkers or lampmakers, can be securely identified and measured. ${ }^{47}$ In other cases, the finds point to the presence of the craftsman, though there is nothing to distinguish his house architecturally, and consequently his non-residential activity is hard to measure: thus the cabinet-maker of the Casa del Fabbro (I 10.7) is identified by an ample set of tools, though no workshop is visible in the house. There are other cases where architecture and finds point to some sort of workshop, without revealing the nature of the activity. Finally there is a penumbra of types that is hard to categorise, like the occasional stableyard (e.g. I 8.12). There were also surely hospitia ('hotels' gives a misleading impression), the identification of which remains conjectural. ${ }^{48}$

The moral is that, as in any archaeological survey, activities that are physically distinctive are likely to be well represented, others under-represented. That is, many houses that are not registered as including non-residential activity may in fact have been the place of work of a craftsman. But for statistical purposes, the safest procedure is to start by looking at units which certainly included non-residential activity, and ask in what ways they distinguish themselves from those whose function is ambiguous. This in turn may assist in sorting out the ambiguous cases.

The total sample includes 122 houses (over half) which either are or incorporate shops (tabernae); 32 are workshops (officinae) or include areas given over to some trade; 17 include horticultural areas (horti). Some houses (13) fall into more than

${ }^{46} \mathrm{~V}$. Gassner, Die Kaufiäden in Pompeii, lff offers good discussion of the usage of taberna, which is used of shops, workshops, 'taverns', and in general of the dwellings of the poor (e.g. Horace, Odes 1.4.13f: pallida Mors aequo pulsat pede pauperum tabernas regumque turris). Further enquiry into Roman terminology is needed here, particularly into the boundaries between tabernae/tabernarii and officinaelopifices.

${ }^{47}$ Trades that have attracted close study are the most visible: B. Mayeske, Bakeries, Bakers and Bread at Pompeii (1972); W. Moeller, The Wool Trade of Ancient Pompeii (1976); G. Cerulli Irelli, 'Officina di lucerne fittili a Pompei', in L'instrumentum domesticum di Ercolano e Pompei nella prima età imperiale (1977), 53-72; R. I. Curtis, 'The garum shop of Pompeii', Cronache Pompeiane 5 (1979), 5-23; and the particularly good survey of metal workshops of Bettine Gralfs, Metallverarbeitende Produktionsstätten in Pompeji (BAR Int. Ser. 433, 1988).

${ }^{48}$ See T. Kleberg, Hôtels, restaurants et cabarets dans l'antiquité romaine (1957); J. Packer, 'Inns at Pompeii', Cron.Pomp. 4 (1978), 30ff and Jashemski, Gardens of Pompeii, $167 \mathrm{f}$. 
TABLE 3

Houses with non-residential usage.

\begin{tabular}{|c|c|c|c|c|c|}
\hline $\begin{array}{l}\text { Quartile } \\
\text { (size) }\end{array}$ & $\begin{array}{c}1 \\
(10-45)\end{array}$ & $\stackrel{2}{(50-170)}$ & $\begin{array}{c}3 \\
(175-345)\end{array}$ & $\begin{array}{c}4 \\
(350-3000)\end{array}$ & $\left.\begin{array}{c}\text { All } \\
(\% \text { of sample }\end{array}\right)$ \\
\hline Tabernae & 50 & 29 & 21 & 22 & $122(53 \%)$ \\
\hline Officinae & 3 & 8 & 13 & 8 & $32(14 \%)$ \\
\hline Horti & 3 & 23 & 24 & 23 & $73(31 \%)$ \\
\hline
\end{tabular}

one of these categories, but fewer than a third have no sign of economic activity. The three types of activity are unequally distributed across the house sizes (Table 3).

There is a clear and comprehensible pattern here. The smallest units are virtually all shops; three are described as 'workshops', but at this level the distinction is minimal. Only three units are excluded; and these (VI 11.1/2, VI 14.29, Herculaneum III.4) are extremely likely to have functioned as workshops too. Much the same applies to slightly larger units: only three more among houses under $100 \mathrm{~m}^{2}$ rate as neither shops nor workshops. But it is not the case that only the smaller units have a commercial side; well over a third of the houses in the top two quartiles also include shops. Horticultural plots go to the opposite extreme: only in the top quartile are they at all common. This is the natural result of the size of a horticultural plot $\left(138 \mathrm{~m}^{2}\right.$ is the average $)$; since these are normally attached to not insubstantial houses, the average total unit size is high $\left(482 \mathrm{~m}^{2}\right)$. Officinae lie in between the two patterns, and are surely (for reasons outlined above) understated. But since the types of artisanal space that shows up unmistakeably (bakeries etc.) tend to require a moderate amount of space (the average is $76 \mathrm{~m}^{2}$ ), they tend to cluster in the medium large range.

It is striking how widespread non-residential activity is among houses of all sizes. Even in the $31 \%$ which appear immune, there may well have been a fair amount of unrecorded activity. We should remember, too, that many of the larger houses which apparently lack shops in fact had them in front rooms whi. $h$ have been blocked off and are inaccessible from the house. These could even so be owned, and either rented by or controlled by, the occupants of the house. The overall picture that emerges is of a wide penetration of economic activity. While there may be a substantial difference between the use of space for economic, i.e. profit-making, activity and its use for social, residential and reception functions, it does not follow that we are dealing with two distinct categories of building, residential and non-residential. Workshops and reception rooms, profit-making and luxury, might sit alongside each other in the same house. Attention to architectural details casts further light on this intermixture.

\section{ATRIA AND PERISTYLES}

A familiar pattern of spatial organisation rates as 'typical' for the Roman house: an axial line runs the depth of the house from the door through fauces, atrium with 
impluvium in its centre, tablinum with wide opening on the atrium and often also a wide window on the peristyle garden behind, with its four neatly symmetrical colonnades around. Atrium and peristyle thus form the essential matrix of this 'traditional' house: they are the twin sources of light, and around them are organised the main reception rooms of the house. 'Ideal' rather than 'typical', this matrix is anything but universal. Partly this is a function of size: a house must be of a certain minimum size to enable construction of an impluviate atrium, let alone of a peristyle. But, more significantly, it is a question of the social use of space. Vitruvius makes explicit the social considerations behind Roman architectural form: spacious public areas in a house are designed for the reception of the public, and he does not expect them to be needed in the houses of the humble. These architectural features simultaneously fulfil a practical function, in letting in light, air, and water, and a symbolic one, in giving dignitas to the home, in a society in which so much turned on social standing. ${ }^{49}$ We might anticipate that these architectural features should provide a good index of the standing of the inhabitants. They are regularly so treated by archaeologists: a house distinguished by these features is often distinguished by modern scholars with the label domus, a practice also applied in discussion of Rome and Ostia, where in a later period the contrast between houses which possessed or lacked them became more marked.

But if this is right, just how exclusive is the atrium/peristyle house? And how far can it be distinguished on other counts, in terms of size, number of rooms, economic activity, decoration, and nature of finds? Identification of these houses presents few problems. The impluviate atrium is betrayed by the basin of the impluvium in the floor; since it needs to catch rainwater, it must be a fairly substantial structure, and the excavators (who in any case tend to start from expectations about the house derived from Vitruvius) both find and record the impluvium. It is true that the displuviate atrium was constructed without an impluvium, and naturally this type does not show up on the ground plan. But the displuviate atrium failed to bring light into the heart of the house, and one may doubt whether it brought in dignitas either. Most houses must have a central circulation space of some sort, even a shop of the front/middle/back room pattern, and these circulation spaces may have been called atria as much as larger and lighter ones. Equally there are houses for which the peristyle acts as only circulation space (e.g. the house in Herculaneum known after its 'Corinthian' atrium, V.30), and these too may in fact have been called atria. It makes sense to treat the impluviate atrium as the distinctive feature (and 'atrium' will be used below to indicate this type of atrium) while remembering that its absence may be explained in a variety of ways.

More subtle is the question of defining the 'peristyle'. The classic image is of a pleasure garden surrounded on four sides by colonnades. These stand out on any plan, and are of course a rarity-only $10 \%$ of the sample. But it would be unhelpful to restrict attention to these. Other, recognisably similar, peristyles only have colonnades on two or three sides; a blank garden wall on the other sides may well have engaged half-columns or even painted representations of columns to give the illusion of continuity. Attention will then extend to the numerous gardens with

${ }^{49}$ As argued in 'The social structure of the Roman house', (above n. 1). 
a portico on a single side, typically that nearest the entrance and tablinum, which may frame the view from the atrium between a pair of columns and thereby give the impression of a full peristyle beyond. And, of course, porticoes are not always constructed with true columns; a couple of square piers may achieve the same effect, of a sheltered walkway communicating between different areas of the house, open on one side to a garden. Finally, there are houses with open areas, whether gardens or not, which serve an important function as light-source and focus of a vista, but which lack porticoes: so the charming nymphaeum with its fine mosaic of Neptune and Amphitrite in Herculaneum (V.7) catches much of the 'dignity' of a peristyle without including any colonnades.

Now, the very statement of these problems already throws a light on the nature of housing and society in the Vesuvian cities. We are not dealing with polarities, of one class of atrium/peristyle house in sharp contrast to a non-atrium/non-peristyle house, but with gradations, spreading like ripples through the different levels of housing. The figures from our samples bear testimony to this ripple-effect (Table 4).

TABLE 4

Frequency of atria and peristyles.

\begin{tabular}{lccc}
\hline Feature & No. $(\%)$ & $\begin{array}{c}\text { Avg area } \\
\text { sq.m }\end{array}$ & $\begin{array}{c}\text { Avg open area } \\
\text { sg.m }\end{array}$ \\
\hline Atrium & $94(41 \%)$ & 480 & 62 \\
Atrium, no garden & $34(15 \%)$ & 224 & 0 \\
Atrium and garden & $60(26 \%)$ & 626 & 98 \\
Garden & $81(35 \%)$ & 552 & 87 \\
Garden, no atrium & $21(9 \%)$ & 341 & 56 \\
Garden, no colonnade & $7(3 \%)$ & 231 & 28 \\
1 colonnade & $22(9 \%)$ & 340 & 63 \\
2 colonnades & $21(9 \%)$ & 433 & 55 \\
c colonnades & $7(3 \%)$ & 408 & 58 \\
4 colonnades & $20(9 \%)$ & 789 & 110 \\
8 colonnades & $4(2 \%)$ & 1970 & 424 \\
\hline
\end{tabular}

Note: 'garden' here indicates open areas which appear to serve an ornamental function, as opposed to horticultural plots. Figures for open area exclude horticultural plots.

The atrium is commoner than the decorative garden $(41 \%$ v. $35 \%)$, and over one third of atriate houses lack gardens. These are, naturally, relatively smaller than those which possess gardens. The average size of the house tends to rise with the number of colonnades; houses that have a garden without colonnades are distinctly the smallest, while those with one, two or three colonnades are larger, but not much different in size from each other. The leap between the average size of houses with one to three colonnades and those with a full four-sided peristyle is marked and at the same time the average area enclosed within the colonnade almost doubles. There is another dramatic leap to those with more than four colonnades, a small handful of double-peristyled houses like the Casa del Fauno, which concentrate, in fact, in Regio VI among this sample. 
The strong correlation between house size and occurrence of atria and peristyles comes out clearly in their distribution across the size quartiles (Table 5). The little shops and workshops that typify the first and much of the second quartile, and most of the little three to five room houses, are too small for either impluviate atrium or colonnaded garden. In fact the smallest house with impluvium is $100 \mathrm{~m}^{2}$, and the smallest with any sort of garden is $125 \mathrm{~m}^{2}$. The smallest with both is $150 \mathrm{~m}^{2}$. In the third quartile both atria and colonnades become commoner, atria in over half the cases, colonnades in slightly more than a third. Single colonnades are much commoner in this range than full peristyles. In the top quartile, by contrast, peristyles $(79 \%)$ are even more frequent than atria $(76 \%)$, and a full third have at least one four-sided peristyle.

TABLE 5

Distribution of atria and peristyles by quartile.

\begin{tabular}{|c|c|c|c|c|}
\hline $\begin{array}{l}\text { Quartile } \\
\text { (size sq.m) }\end{array}$ & $\begin{array}{c}1 \\
(10-45)\end{array}$ & $\stackrel{2}{2}$ & $\begin{array}{c}3 \\
175-345)\end{array}$ & $\begin{array}{c}4 \\
(350-3000)\end{array}$ \\
\hline Atrium & 0 & 16 & 34 & 44 \\
\hline Garden, no colonnade & 0 & 1 & 5 & 1 \\
\hline 1 colonnade & 0 & 3 & 10 & 8 \\
\hline 2 colonnades & 0 & 1 & 5 & 15 \\
\hline 3 colonnades & 0 & 0 & 2 & 5 \\
\hline 4 colonnades & 0 & 0 & 4 & 16 \\
\hline 8 colonnades & 0 & 0 & 0 & 4 \\
\hline
\end{tabular}

There is also a regional contrast to observe. Both atria and peristyles seem to be more common in Pompeii than Herculaneum. Only 29\% of the Herculaneum sample have atria, as against $42 \%$ in Pompeii Regio I, and $45 \%$ in Regio VI. Partly this is attributable to the somewhat different balance of sizes in Herculaneum, which has a smaller proportion of the houses in the top quartiles, and a greater proportion under $100 \mathrm{~m}^{2}$ in which atria are unknown (above, Fig. 2). But that changing architectural fashions are also involved is suggested by a group of handsome houses that lack impluviate atria (V.30, Atrio Corinzio; III.3, dello Scheletro; IV.3/4, dell' Alcova; IV.21, dei Cervi). These include one of the most magnificent houses in Herculaneum, and it does seem to be the case, as Maiuri observed, that here we can already see the beginning of a shift away from the atrium matrix.

Size emerges as an important factor in explaining the presence or absence of atria or peristyles. Below a certain level houses cannot possess these features, and above a certain level they are more likely to. But exceptions are numerous enough to make it clear that there are other factors at work. In particular it is clear that certain economic activities, like horticulture, baking, fulling, stabling etc., required large areas. Such activities are common in large houses without atria. In the top two quartiles, that is in those houses which had ample room architecturally, 37 houses $(32 \%)$ lack atria. A good many of these were substantially involved in economic activity of one sort or another: 7 have large horticultural plots; 13 have 
substantial areas given over to various economic activities, including a bakery (I 12.1/2), a supposed weaver's workshop (Herculaneum V.3-4), a garum making establishment (I 12.8), and two stables (VI 15.16 and 20). There is also an interesting group of houses without atria built round a four-sided peristyle that look like possible hospitia (Herculaneum IV.17/18; I 12.6; VI 15.23; also perhaps I $11.9 / 15$ and VI 11.4/15-17).

Yet economic activity does not necessarily 'degrade' a house, though two fulleries in atrium/peristyle houses (VI 14.22 and I 6.7) have been supposed to do so. A significant number of large houses combined economic with reception functions. The Casa del Labirinto (VI 11.9-10) includes its own bakery, the Casa del Menandro (I 10.4) its own stableyard. The important distinction is not between houses with a reception function and those with an economic one, but between the houses with an economic function that do and do not have a reception function in addition. For this purpose, the presence of an atrium is a valuable indicator of reception activity, and a marked contrast emerges between those houses with atria and those without in which horticulture or other 'industrial' activity is attested (see below Table 6). Those with atria tend to be larger, both in terms of area and number of rooms, and as we will see below, far more elaborately decorated. The implication is that there was nothing to stop a grand house with a reception function from supporting economic activities as well.

\section{DECORATION}

What exactly does the presence or absence of decoration tell us about a house? To traditional Roman morality, painted walls and mosaic-carpeted floors spelled luxury. When decorated plaster first appeared, seemingly in the early second century B.c., on Roman walls, it was a luxury which could provoke outrage: Cato could boast that none of his walls had stucco, and threatened to expose the corruption of those who had villae expolitae. ${ }^{50}$ Later refinements in turn struck contemporaries as outrageously indulgent: Lucullus' 'picture-gallery' decorations attracted censorious comment at the end of the Republic, ${ }^{51}$ Augustan rhetoricians declaimed against decorations that imitated landscapes and seascapes, and still in the Flavian era the elder Pliny protested against entrusting art to walls which could not be removed and saved in case of fire. ${ }^{52}$ Even sober lawyers took a moralising view. Not only did expenditure on wall decoration count as the opposite of a 'useful expenditure'; lawyers disapproved of allowing excessive costs for damage compensation for such paintings. So, according to Capito, one might have extremely expensive decoration on a common wall, but if the neighbour demolished it, one could only reclaim for the price of plain plaster (Dig. 8.2.13.1). Ulpian similarly was of the opinion that only moderate costs could be allowed in this situation,

\footnotetext{
${ }^{50}$ Cato fr. 175 Malcovati = Plutarch, Cato ma. 4.4 ; $\mathrm{cf}$. fr. 185 for his criticisms of others.

${ }^{51}$ Varro, $R R$ 1.2.10; cf. 1.13.7; against frescoes and mosaic floors in general 3.1.10, 3.2.4 etc.

${ }^{52}$ Papirius Fabianus in Seneca, Controversiae 2.1.13 (I owe this reference to Catharine Edwards); Pliny, NH 35.118.
} 
because one should not pander to luxury (non immoderata cuiusque luxuria subsequenda, 39.2.40). On the other hand, it was acknowledged that decoration could so enhance the value of a house that it might actually be bought for its adjuncts, marbles, statues and painted pictures (18.1.34), and such was the value of a pictura that it could be an exception to the rule that everything attached to somebody's property belonged to that property (6.1.23.3).

Luxury presupposes wealth, and naturally decoration must indicate wealth. But, as $\mathrm{I}$ have argued in detail in an earlier paper, ${ }^{53}$ decoration points to something rather more specific than wealth. A rich man does not decorate all areas of his house indiscriminately, from triclinium to kitchen or slave's bedroom. On the contrary, the function of decoration is to discriminate, and to render the house fit for the pattern of social activity within it. The language of private decoration draws on the language of public life; decoration reflects the reception function of a house and the expectations of contact with visitors from outside. Decoration (or its absence) should tell us in the first place about the social use of space; this will have its implications for the social position and wealth of the inhabitants. This working hypothesis must now be tested against the evidence available.

Measuring the 'luxury' of decoration is bound to be somewhat arbitrary. Wall decoration in particular presents us as we meet it with such a bewildering variety: in its present condition of preservation, from the washed-out and crumbling to the immaculate; in period of execution, over the two centuries or so covered by Mau's four decorative 'styles'; and in elaboration of detail and fineness of execution, ranging from the crudest daubings on rough whitewashed plaster to extraordinary confections of breathtaking artistic skill. Moreover, walls often tell a complex history over the course of decades and even centuries: of decoration and redecoration, of adaptation and repair, especially in the wake of the earthquake damage that preceded the eruption. No statistics can do justice to the complexity of the individual variants. For purposes of comparison of a large group of houses it is necessary to simplify, sometimes drastically. Even so, enough of the contrasts can be caught to form the basis for valid comparisons. Here the inventory of Pitture $e$ Pavimenti di Pompei is of great assistance. Because each photographic record number is accompanied by a verbal description of detail and an assignment to chronological style, a considerable level of detail is preserved on a systematic basis. Indeed, one might almost measure the decorative elaboration of a house by the length of its entry in Pitture e Pavimenti: in the finely decorated houses, not only is there physically more to record and describe, but its description requires a higher degree of verbal elaboration. In fact we can use less crude measures; but it is worth noting that the samples chosen for study here represent a considerable proportion of the whole compilation: the Regio I sample occupies 166 of the 256 pages of vol. 1; the Regio VI sample 194 of the 376 pages of vol. 2. The samples have been chosen because of the relative wealth of information available.

Wall decoration allows itself to be measured in different ways in order to answer different questions. First, it is possible to give a rough measure of the presence and extent of decoration in a house by counting the number of rooms decorated with

53 'The social structure of the Roman house', (above n. 1). 
anything more elaborate than bare plaster. For this purpose I have reckoned as a 'room' any space which is given a separate number on the house plan, including public areas, corridors etc. (and it should be noted that this is a more generous definition than 'rooms' counted for the purpose of measuring house size). The value of this room-count is limited: obviously a house with two magnificently decorated rooms might be 'preferable' to one with ten crudely decorated ones in a state of poor repair. But within its limitations, it offers a highly convenient measure of simple extent of decoration. Secondly, the vast majority of these decorated rooms can be assigned uncontroversially to one of the four decorative periods, and it is revealing to count the distribution of rooms between the styles. For this purpose I have followed the assignments of Pitture $e$ Pavimenti (and have ignored fragments of an earlier phase preserved in a decoration of later period, and equally later repairs and patchings in decoration of an earlier period).

Quality is much harder to quantify. I have not presumed to make an arbitrary judgment of decorative quality of each room or even each house. It is, however, possible to take note of certain outstanding features. One such feature which is characteristic of Roman painting of the imperial (but not republican) period is the mythological painting, a formally constructed scene, in a Hellenising idiom, of a subject from Greek mythology (still lives, landscapes, vignettes of animals etc. fall outside my definition). What makes the distribution of these 'mythologicals' potentially interesting is not only their frequency (and the care with which excavators have recorded and preserved them), but their close connection with the luxury world of the Roman elite, and the 'works of art' pillaged from Greece in the late Republic. Similarly, mosaic floors and designs of polychrome marble point directly to the luxury of the elite (moralists protested at their lithostrota).${ }^{54}$ Mosaics, like mythologicals, have been counted according to the number of rooms in which they occur (or are recorded as having occurred).

Mosaics and mythologicals are relatively restricted in diffusion. It would be nice to have some measure that allows for qualitative distinctions right across the spectrum of diffusion. Comparisons across different styles of painting would be dubious; but the fourth and final Pompeian style is both sufficiently common in its occurrence and varied in its range of elaboration to allow some tentative comparisons, though I have restricted the exercise to a single sample area, Regio I.

It remains to be seen what emerges from the data collected and what inferences can be drawn. I shall look in turn at (a) the pattern of diffusion of decorative features; (b) the relationship of decoration to social and economic activity; (c) changes over time; and (d) the relationships between different social levels.

\footnotetext{
${ }^{54}$ The classic study is still E. Pernice, Die hellenistische Kunst in Pompeji VI. Pavimente und figürliche Mosaiken (Berlin 1938). M. De Vos, 'Pavimenti e mosaici' in Pompei 79. Raccolta di Studi, ed. F. Zevi (1984), 161-76 comments on the rarity of mosaics, which constitute on her figures $2.5 \%$ of the available floor space (p. 162). On the lithostrota decried by moralists, M. Donderer, $J d I 102$ (1987), 365-77. Floors have been little studied in comparison to walls, and almost never in conjunction, as should be the case.
} 


\section{(a) The diffusion of decoration}

We may begin by remarking the sheer extent of wall decoration in our samples from Pompeii and Herculaneum. Even excluding certain types of decoration which fall outside the art-historical classification of the 'four styles', and which are rather different in function from such decoration, like lararia paintings and decorated shop-counters (and to these I shall return), there remain in the whole sample 137 houses or well over half $(59 \%)$ with at least one decorated room or area, with some 740 decorated rooms or areas between them (average 5.4 rooms each). But this is certainly an understatement of the picture in A.D. 79. First, we must remember that we are only looking at ground floors. But where upper floors survive, it seems that decoration was normal. Thus in the Herculaneum sample, rooms survive in a state of good preservation above six houses (III.13/14; V.6/7; V.8; V.15; V.17; V.22), all of which have decorated walls, and even in the Pompeii Regio I sample, upper rooms survive above five houses $(\mathrm{I} 7.18 ; 10.1 ; 10.4 ; 10.18$, all these four very close to each other; and 11.9/15, the Casa del Primo Piano), and again all are decorated. In many houses where only fragments of walls from upper stories are standing, traces of decorated plaster can be seen. There can be little doubt that if the survival of upper floors were less fragmentary, the picture of the extent of decoration would be further extended.

Secondly, we must allow for the sheer disintegration of evidence. In Regio I of Pompeii and in Herculaneum, it is relatively well preserved; as far as one can tell, though the condition of numerous walls has deteriorated, sometimes dramatically, there is still no room where the decoration has been completely obliterated. In the Regio I sample, $71 \%$ of houses have some decoration. But the Regio VI sample has suffered very badly over the years, particularly in the smaller houses, and its $50 \%$ of decorated houses might well reflect a reduction by $20 \%$ or more through simple neglect. (Insulae 10 and 11, excavated over 150 years ago, have surviving decoration in only 8 out of 23 houses.)

But even though the figures for Regio VI are likely to be an understatement, there is a clear pattern in the distribution of houses with some sort of decoration. Figures 4 and 5 examine their distribution across the size quartiles.

The chances of the smallest units to carry decoration are slim (the reasons will be examined in due course); on the other hand, it is very rare indeed for the houses in the top size quartile to be completely undecorated, and since 4 of the 5 cases occur in Regio VI, loss of evidence is the most likely explanation. In the middle two quartiles the likelihood of decoration increases with size, except in Regio I, with its steep rise in the second quartile. In fact there is a cut-off point at about $100 \mathrm{~m}^{2}$ : below this size decoration is unusual-14 houses $(17 \%)$ in the whole sample-but above that point the chances of decoration increase rapidly. It is particularly in this middling range that Regio VI seems to be badly under-represented. This results in a misleading impression of the contrasts between the grand houses and the small (cf. above, I).

Just as the chances of being decorated at all rise with size, so the number of rooms/areas decorated rises. The average number of decorated rooms/areas in those houses which preserve decoration in the first quartile is 1.5; in the second, 2.5; in 


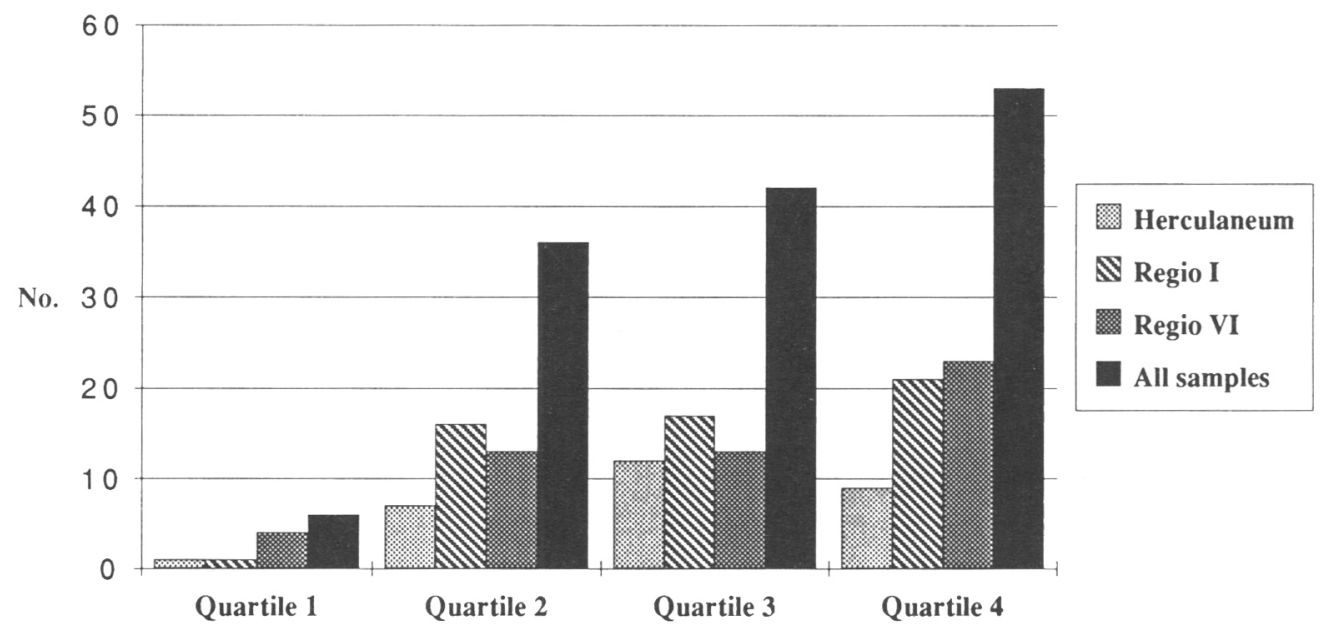

Fig. 4. Distribution of houses with at least one decorated room (no. of houses).

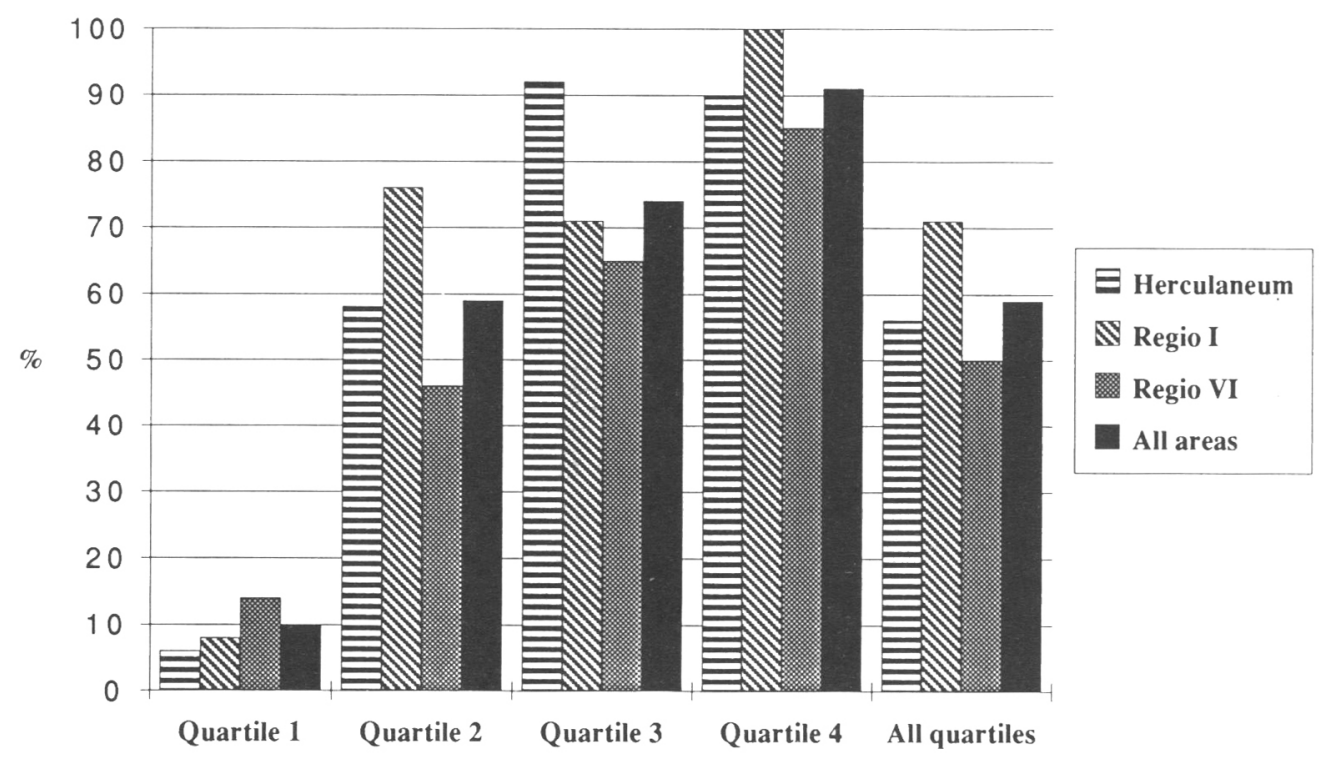

FIG. 5. Distribution of houses with at least one decorated room $(\%)$. 


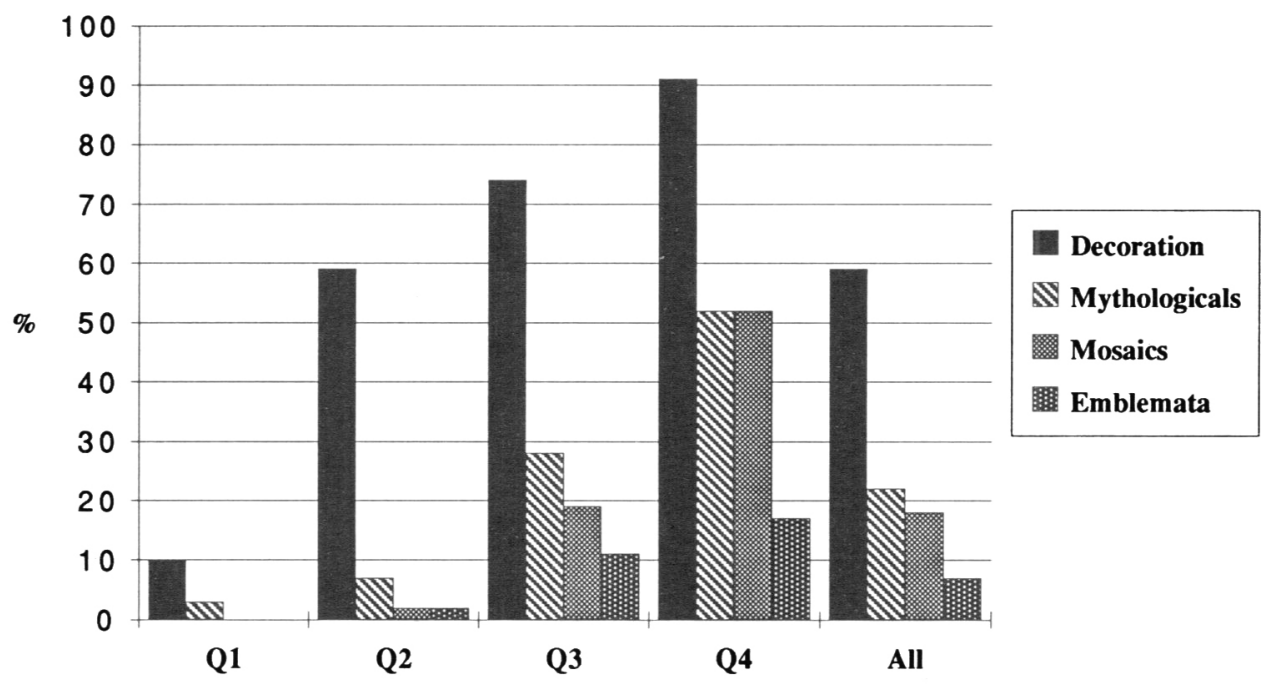

FIG. 6. Distribution of decorative features.

the third, 4.3; in the fourth, 8.6. It would be strange if this were not the case, since we have already seen that the number of rooms increases with the size of the house. But it is certainly not the case that decoration always rises in proportion to number of rooms. On the contrary, there are very large houses with very little decoration (or at least little surviving), and relatively small ones with nearly every available space decorated. Extent of decoration thus becomes a valuable measure of status display when taken in conjunction with size.

The distribution of the special features of mythologicals and mosaics is much more restricted than that of wall decoration in general (Fig. 6). Less than a quarter of houses overall have mythological paintings, less than a fifth mosaic floors. But these special features correlate strongly with house size, so that they are found in over half the houses in the top quartile, but become highly exceptional in the bottom quartile. Even rarer are the rich panels of mosaics or polychrome marble intarsio which may form the centrepiece of the floor of a particularly important reception room ('emblemata'). Again, the distribution is tilted markedly towards the larger houses.

Not all grand houses necessarily contained either mythologicals or mosaics. Grand houses in Herculaneum like the Casa del Salone Nero (VI.13) which are richly decorated in other respects suggest that it was by no means necessary for a prestigious Roman house to be decorated with mythologicals. There seems indeed to be a slight contrast between Pompeii and Herculaneum, which emerges from comparing the distribution of mythological paintings and mosaics in the three samples. In Herculaneum only $17 \%$ of the houses in the sample have mythological paintings, as against $23 \%$ in Pompeii Regio I, $24 \%$ in Regio VI. Conversely, mosaics are found in $25 \%$ of the Herculaneum sample, but only $14 \%$ of Pompeii Regio I, $17 \%$ of Regio VI. It would appear that the houses of Herculaneum 
express their distinction in mosaics in preference to mythological paintings, and it is of course possible that there were contrasts in fashion between the two towns. However, the Herculaneum sample is not large enough for these contrasts to be regarded as statistically significant.

Two points emerge clearly from analysis of the distribution of decoration. The first is that there is a predictable correlation between size of house and lavishness of decoration. The larger the ground area of a house, the more likely it is to have decoration, the more numerous the decorated rooms it will tend to have, and the more luxurious features among them. Decoration and house size both evidently operated as status markers, and consequently correlated. The second and related point is that we are not dealing with a dichotomy, between grand and richly decorated houses of the 'elite' on the one hand, and the undecorated houses of the tradesmen on the other, but with a continuous spectrum. The same status markers that are found in the very grandest houses also occur, albeit more rarely and in more modest quantities, in quite small units; and between largest and smallest lies a significant middle ground. Houses in the bottom quartile (and in fact houses smaller than $100 \mathrm{~m}^{2}$ ) only exceptionally have decoration of any sort, though even among these mythological paintings can be found. Houses in the second quartile regularly have some, but not much decoration, and little of special quality. Houses in the third quartile are regularly decorated, more extensively so, and sometimes have special features like mosaics and mythologicals. In the top quartile, it becomes remarkable if a house lacks decoration; it is normally abundant, and in at least half the cases there are special features.

\section{(b) Decoration and function}

Two overlapping modes of explanation for the absence of decoration are possible. One is poverty: either the inhabitants simply could not afford to decorate, or they were tenants for whom the landlord did not think it worth decorating. ${ }^{55}$ The other is function: the purposes which the 'house' or unit served were such that decoration was either inappropriate or superfluous. The two explanations could converge: Vitruvius' picture of the appropriate housing for different social levels lays heavy emphasis on function, and assumes that the lowlier plebeians both would find rooms for the reception of visitors unnecessary and would need rooms suited to rustic and other functions. ${ }^{56}$ However, rather than following Vitruvius in assuming this convergence, it is worth examining the evidence to see what light it casts. We have seen that evidence for economic activity of different types is found in houses of all sizes (above, IV), and that the architectural features of atrium and peristyle offer a useful index of reception function $(V)$. How does decoration correlate with these indicators?

\footnotetext{
${ }^{5}{ }^{5}$ Gassner, Die Kaufläden in Pompeii, 13 rightly suggests that the renting of tabernae must, to judge by literary sources, have been the normal pattern. Further, 'Houses and households', (above n. 1).

${ }^{56}$ Vitruvius 6.5.1-2: 'So those of common fortune have no need of magnificent vestibules or tablina or atria, because they pay their respects going round the houses of others, and are not themselves called upon.'
} 
Shops are a good starting point. We have seen that units in the bottom quartile, and generally those under $100 \mathrm{~m}^{2}$, are rarely decorated. But we have also seen that units in the bottom quartile are almost universally shops or workshops. There is no clear case of a unit under $100 \mathrm{~m}^{2}$ that does not include a shop, workshop or, in one case (I 8.12), a small garden plot. Can we distinguish whether function or poverty was responsible for their lack of decoration? Two tests are possible. One is to compare these units with the shops that are frequently incorporated in the frontages of larger units. 123 houses in the total sample are or include a total of 143 shops; $73(51 \%)$ of the shops form part of units under $100 \mathrm{~m}^{2}, 70(49 \%)$ belong to larger units. Of these 143 shops, only $29(20 \%)$ are decorated in any fashion. Among those decorated shops, 9 belong to units under $100 \mathrm{~m}^{2}, 20$ to larger ones. It would appear that shops forming part of larger units did have a better chance of decoration, and that poverty therefore (or the indifference of the landlord) was a possible factor. But it is also clear that among shops of any sort, decoration was uncommon.

The second test is to compare the sort of decoration found in shops with that found elsewhere. It soon emerges that it is far from being the type of 'drawing-room' decoration to be found in a private house. ${ }^{57}$ Sometimes the shopcounter is the focus of embellishment; 5 of the 29 'decorated' shops have merely decorated counters. In three cases decoration is limited to lararia, which I have excluded from the reckoning for decoration elsewhere (I return to this below). In three shops (I 6.12; VI 16.32; H IV.17) the decoration consists of a fairly crude phallic or Priapic scene of a type and style not normally met inside houses. In general, shop decoration is cruder in execution, and in the rare cases in which decoration of the standard residential type is met, it occasions surprise. Thus in Herculaneum, a shop (V.17) neighbouring the Casa del Bicentenario pleasantly decorated in red and yellow with a handsome backroom surprises Maiuri: 'The decoration on the ground and upper floors is rather high-class (piuttosto signorile) and seems more suitable for a family of good class (di buon ceto) than for a retail outlet... ${ }^{58}$ Here as elsewhere Maiuri is too ready to assume that nice decoration can only have been put up by those 'di buon ceto'; but his remark underlines the rarity of meeting a nicely decorated shop. (In fact, VI.16 in the same town, excavated after his time, is an even finer example of a smartly decorated shop.) It is possible in these cases, and certain in others (e.g. the third-style backrooms of I 6.10 and 12), that the decoration dates to a period before the conversion of the room to commercial use. But even a taberna can serve a reception function, and one should take note of the tavern at VI 10.1/19 with its drinking room surrounded by scenes of gambling and daily life, and its little backroom with paintings of Aphrodite

\footnotetext{
${ }^{57}$ Shop decoration is well discussed by Gassner, Die Kaufläden in Pompeii, 35f. On her reckoning, up to half the shops in Pompeii have some traces of plaster; but this is rarely anything more than simple white, or a high red socle with white above.

${ }^{58}$ Maiuri, Ercolano. I nuovi Scavi, p. 238. Further, 'Elites and trade in the Roman town', (above n. 1).
} 
fishing and Polyphemos and Galateia, and also of the bar, 'clubroom' or whatever with very similar mythological scenes at VI $14.28 .{ }^{59}$

Shops then suggest strongly that function as well as lack of resources explains the absence of decoration. A similar pattern emerges in those houses which include artisanal or horticultural activities. Examination of architectural features (see V above) suggested that economic activities ought not be seen as an alternative to a reception function. The real contrast seemed to be between horticultural/industrial establishments that did and did not have architectural features pointing to a reception function alongside any economic function. The distribution of decoration among these houses confirms this pattern to a remarkable extent. This is most apparent if we look at those houses in the top two quartiles, i.e. those unlike the shops and workshops of the bottom two quartiles in which there might not even be room for atrium construction. Table 6 suggests that the presence or absence of decoration is closely tied to the reception function implicit in the impluviate atrium.

Table 6

Decoration of horticultural and industrial houses in top 2 quartiles.

\begin{tabular}{lcccccc}
\hline & No. & $\begin{array}{c}\text { Avg area } \\
\text { sq.m }\end{array}$ & $\begin{array}{c}\text { Houses } \\
\text { decorated }\end{array}$ & $\begin{array}{c}\text { Rooms dec. } \\
\text { per house }\end{array}$ & $\begin{array}{c}\text { Houses with } \\
\text { mythologicals }\end{array}$ & $\begin{array}{c}\text { Houses zoith } \\
\text { mosaics }\end{array}$ \\
\hline $\begin{array}{l}\text { Horticultural } \\
\text { with atrium }\end{array}$ & 7 & 664 & 6 & 8 & & \\
$\begin{array}{l}\text { no atrium } \\
\begin{array}{l}\text { Industrial } \\
\text { with atrium }\end{array}\end{array}$ & 9 & 410 & 5 & 1 & 1 & 3 \\
no atrium & 11 & 610 & 11 & 8 & 7 & 3 \\
\hline
\end{tabular}

Whatever the economic activity, the houses with atria have at least some surviving decoration, and on average in a large number of rooms ( 8 per house); mosaics and mythologicals are common. Those houses without atria may have some decoration, but it is sparser and poorer. The exceptions prove to be anomalous. The only house in this class with an atrium that lacks decoration is VI 9.1 in Pompeii; classified as a hospitium with attached stables, it was excavated in the mid-nineteenth century, and has lost its decoration; in fact it originally had a mythological scene of Io. By contrast, the only house without atrium which does have a mythological is I 9.3/4 (Casa di Successus); it has a colonnade overlooking its garden, which may in consequence be an ornamental one, rather than a horticultural plot.

The evidence for horticulture and industry points in the same direction as that for shops. Function plays a critical role in the distribution of decoration. Decoration played a vital role in social life, but was superfluous to most economic

\footnotetext{
${ }^{59}$ Illustrated by M. de Vos, Meded.Ned.Inst.Rom. 1977, pl. 54-5. Gassner 1.c. for the tiny handful of other 'nicely' decorated shops.
} 


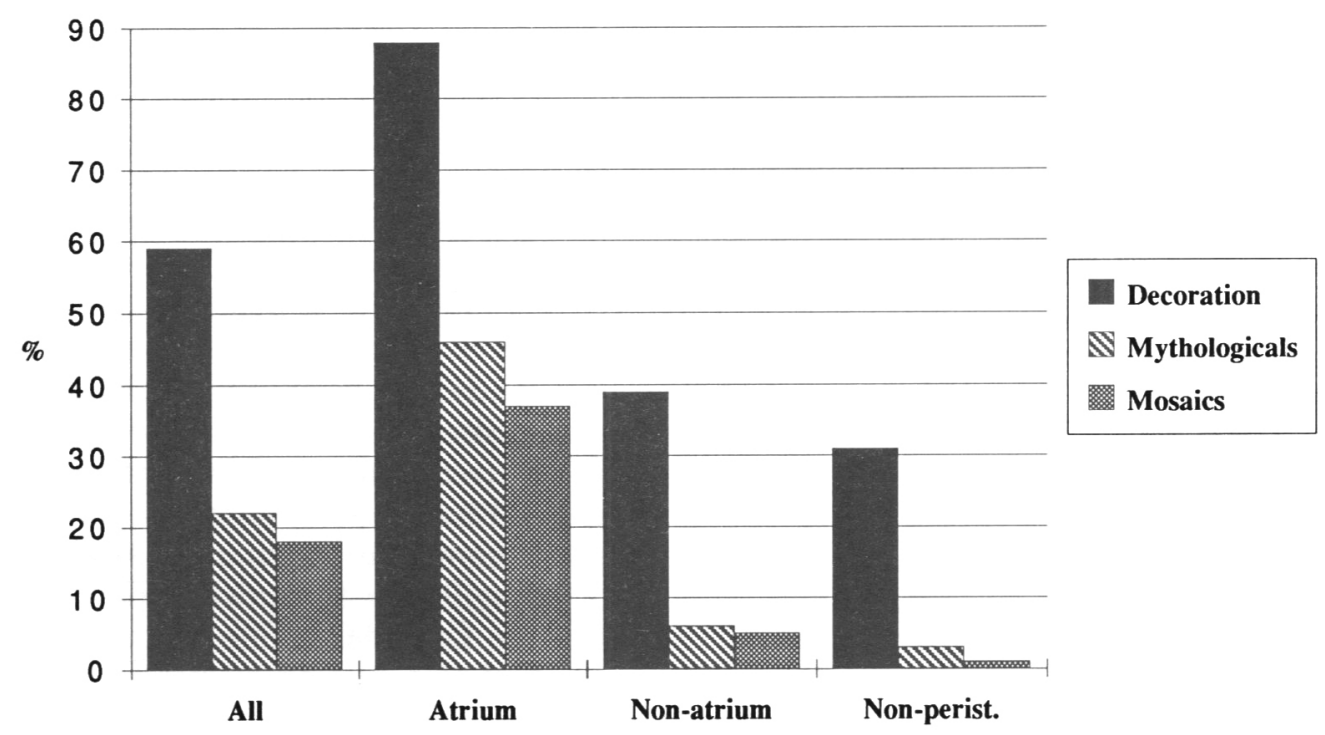

Fig. 7. Distribution of decorative features by house type.

activity. The presence of economic activity in a house by no means precludes decoration; but where this is found, it surely points to social activity alongside the economic.

One of the most striking points to emerge is the value of the atrium as an index of the sort of social activity that gives rise to decoration. If we consider the whole sample (Fig. 7), it is clear that atrium houses have a very much better chance of being decorated than those without atria, and exceptional features like mythologicals and mosaics cluster in them in a very marked way.

It is inevitable that decoration should be commoner in atrium houses, given that it is rarer in smaller houses, and that for structural reasons alone a majority of the small houses could not have atria. But size is not the only factor at work. There are, after all, both small atrium houses, and large non-atrium houses. Yet atrium houses, however small, almost always have decoration; of the 11 which lack it, 8 are in Regio VI of Pompeii, the area where the destruction of evidence is worst, and it is safe to assume that most these were in fact decorated. On the other hand, in non-atrium houses, though the presence of some decoration is not uncommon, fine decoration (mythologicals and mosaics) is extremely rare; and when we except those houses (notabiy in Herculaneum) in which a peristyle functions as an alternative to an atrium, fine decoration disappears almost completely. The exceptions deserve remark, particularly three taverns with mythological paintings on their walls (Pompeii VI 10.1; VI 14.8; VI 14.28) and the highly unusual Sacello degli Augustali at Herculaneum, with a large mythological painting in its central shrine. The one house with neither atrium nor peristyle to boast a mosaic floor is the no less unusual Casa del Bel Cortile at Herculaneum (V.8), with its central courtyard and stairwell, and its enormous reception room ( 5.50 by 10 metres), not 
adequately accounted for by Maiuri (384ff.), but I would suggest to be seen as the meeting place of some public body like a collegium.

\section{(c) The chronology of diffusion}

The data from our sample point to a remarkable diffusion of decoration through the housing stock of Pompeii and Herculaneum, and to the sort of imitation of the Roman elite which Cicero describes, however attenuated. But it points to the year A.D. 79. We are looking at the accumulated results of a cultural explosion dating back to the second century B.c. and apparently already past its apogee by the reign of Titus; the richness of experimentation and the speed of development over this period is stunning, and certainly in the case of wall decoration was not sustained in later centuries. It would be of great benefit to build back a chronological element into the analysis. Partly, one cannot stop at commenting that a house is 'decorated'. The decoration might be fairly fresh as in the Casa dei Vettii; or it might date back as much as two centuries as in the Casa del Fauno. Should that make a difference to our estimation of the current inhabitants in A.D. 79? But more interestingly, it would be valuable to look at the chronology of the process of diffusion. If the luxury of the elite spread outwards in society, how swiftly did the ripples move?

Here at least we are on well-worked terrain--well-worked to a fault. In the late-nineteenth century, August Mau, by basing himself on systematic examination of what was effectively a sample, the current excavations of his day (mostly in the Regio VI sample used here), was able to establish a firm chronological framework for the phases of decorative fashion. Mau's framework of four styles, based on the assumption that Pompeii reflected Roman fashions as described by Vitruvius, has proved its value by its relevance for analysing mural decoration of the same period not only from all over Italy, but increasingly from the provinces. Many modifications in detail have been made since: but the consensus remains firm that the first or 'masonry' style evolved in the second century B.c.; that the second 'architectural' style came in early in the first century B.c. and flourished in the last generation of the Republic; that the third style came in with the Empire (and by a nice twist of fate Augustus' own house on the Palatine has become a prime document in dating this change of fashion); and that a fourth style, in many respects merely an extension of the third style, but also harking back to the second, took over in the Julio-Claudian period, perhaps in the reign of Claudius. ${ }^{60}$

Social and cultural history does not operate with the sharp and precise caesurae of political history, and in dating the diffusion of a cultural pattern it is not even desirable to operate with a more precise dating framework than that sketched above. The point should also be made that the 'style' of a piece of decoration only strictly gives us a terminus post quem. It has been demonstrated repeatedly that earlier

\footnotetext{
${ }^{60}$ See now the excellent study of W. Ehrhardt, Stilgeschichtliche Untersuchungen an römischen Wandmalereien von der späten Republik bis zur Zeit Neros (Mainz 1987), esp. 1-12 on external dating criteria.
} 
styles were imitated, repeated, echoed, restored generations later. ${ }^{61}$ A fourth style decoration cannot have been executed under the Republic; but a second style painting may occasionally have been executed in the first century A.D. With this caveat in mind, we may ask what is the relative diffusion of the four styles.

The difficulty in this enquiry lies in the survival of evidence. It is well known to all that the fourth style is enormously much commoner in Pompeii than the first or second. But that is inevitable, since it is the most recent. Frequently, earlier decorations have been replaced, and fragments of the older styles can still be seen under or embedded in decorations of the imperial period. There was extensive rebuilding as well as redecoration; inevitably numerous walls which once had decoration in earlier styles have been demolished, and it is not until the true excavation of Pompeii starts, and dismantles walls and examines beneath floor levels, that a credible picture of pre-imperial Pompeii can be reconstructed.

To this extent our hands are tied, and a count of the relative frequency of the four styles can tell us nothing. But though we cannot measure frequency, we can observe something of the extent of social spread. ${ }^{62}$ It is possible to contrast the types and sizes of houses in which decorations of the various styles survive. That is to say, although the early styles are sure to be badly under-represented, we can still contrast the proportion, e.g. of houses in the bottom quartiles to those in the top quartile, or of atrium to non-atrium houses, which preserve the early styles, to similar proportions in the case of the most recent and best preserved style. If the habit of decoration really was spreading downwards through society over the two centuries and more in question, we would expect the proportions to drop over time: the early styles should dominate proportionately in the largest houses, the later styles less so.

Of course, these observations would be undermined if there were reason to suppose that earlier phases of decoration were less likely to be preserved in one size or type of house than another. One problem is that of changing property boundaries. The house in which a first style decoration was first put up may have been rather different in size and type from that in which it survives. Thus the fine first style fauces of the Casa Sannitica at Herculaneum lead into what is certainly an atrium of early construction; but Maiuri is probably right to conjecture that the original house was much more extensive than the house of A.D. 79. In this case the occurrence of first style in a small house would not prove that small houses were decorated in the second century B.c. (but it would be an instance of an atrium house decorated in the second century B.C.). Though property boundaries change over time in both directions, and small houses are amalgamated into large, as well as large ones being split up into small, the general tendency is to fission rather than fusion. Numerous small and medium houses of imperial Pompeii and Herculaneum are the result of progressive subdivision. To take another clear example, the magnificent Casa del Criptoportico (I 6.2/4), which must have been one of the

\footnotetext{
${ }^{61}$ For imitations of earlier styles, cf. Ehrhardt, 133ff; Schefold, Vergessenes Pompeji, 140ff; A. Laidlaw, The First Style in Pompeii: Painting and Architecture (Rome 1985), 42-6.

${ }^{6} 2$ I am grateful to Jean-Paul Descoeudres who, by pointing out the rarity of early decorative styles in smaller houses, suggested this approach to me.
} 
largest and finest houses of late republican Pompeii, was split into two properties. In one, the cryptoporticus with its luxurious baths was reduced to a storage area; in the other, the handsome suite of the Sala degli Elefanti which once opened onto the porticus has become the rear room of a house in the process of fourth style redecoration. But this process of fission should tend to exaggerate the proportion of early styles in smaller houses.

Secondly, it is conceivable that the survival of earlier decorations is not random in the sense we would require. The most obvious distortion would be if wealthier owners in larger houses more frequently redecorated their walls, while poorer ones more often made do with out-of-date decoration. In fact this is not the case: indeed, the largest house in Pompeii or Herculaneum, the Casa del Fauno, is the one which preserves the most complete and extensive first-style decoration we have, while the best specimens of second style come from opulent villas outside Pompeii, Oplontis and the Villa dei Misteri. If we fail to find decoration of the period in humbler houses, we will scarcely be tempted to imagine that the humble systematically destroyed what the rich so lovingly preserved.

Let us examine the data. In Herculaneum first and second style decoration is too rare to be revealing, and the lack of a volume of Pitture e Pavimenti means that strict comparability is not possible. For this purpose, then, the sample is restricted to the two Pompeii regions. Figures 8 and 9 analyse the houses in which rooms predominantly decorated in one of the four styles occur by size quartile and house type.

Even when all allowances have been made for the limitations of our evidence, the pattern is too marked to leave room for much doubt. The republican styles cluster in a very pronounced fashion in the largest houses. The smallest house in the sample which has first style decoration is $125 \mathrm{~m}^{2}$, the smallest with second style 140 $\mathrm{m}^{2}$. There is, that is to say, no sign of shops and workshops at the lower end of the scale having been decorated in the republican period. The same applies to shops incorporated in larger units: just one (VI 14.11) had first style decoration, and that presumably dates from a period when it was a room in the adjoining house (14.12), which has first-style decoration in its vestibule. Even third style is exceptional among shops: four cases among all shops in the sample include two which were previously private rooms within the Casa dei Quadretti Teatrali (I 6.10 and 12). By contrast, 15 shops in the Pompeii sample have fourth style decoration, and though it may still be the case that shop-decoration remained unusual, it is clearly only towards the end of its history that decorating fashion penetrated to shops.

It would also appear that the decoration of small to middling houses (i.e. those in the second and third quartiles) was unusual under the Republic, though not unknown. In the top quartile, there is a steady increase in numbers of decorated houses from style to style, but no sudden leap. But in all other quartiles, the pattern changes dramatically between republican styles (I and II) and imperial (III and IV). So if one looks at the proportion of decorated houses in the first three quartiles as against those in the top quartile (Table 7), it changes dramatically between the republican and imperial periods. While under the Republic, decoration is two to three times commoner in the top quartile than in all other houses put together, under the Empire the balance becomes an equal one. This is strongly supported by 


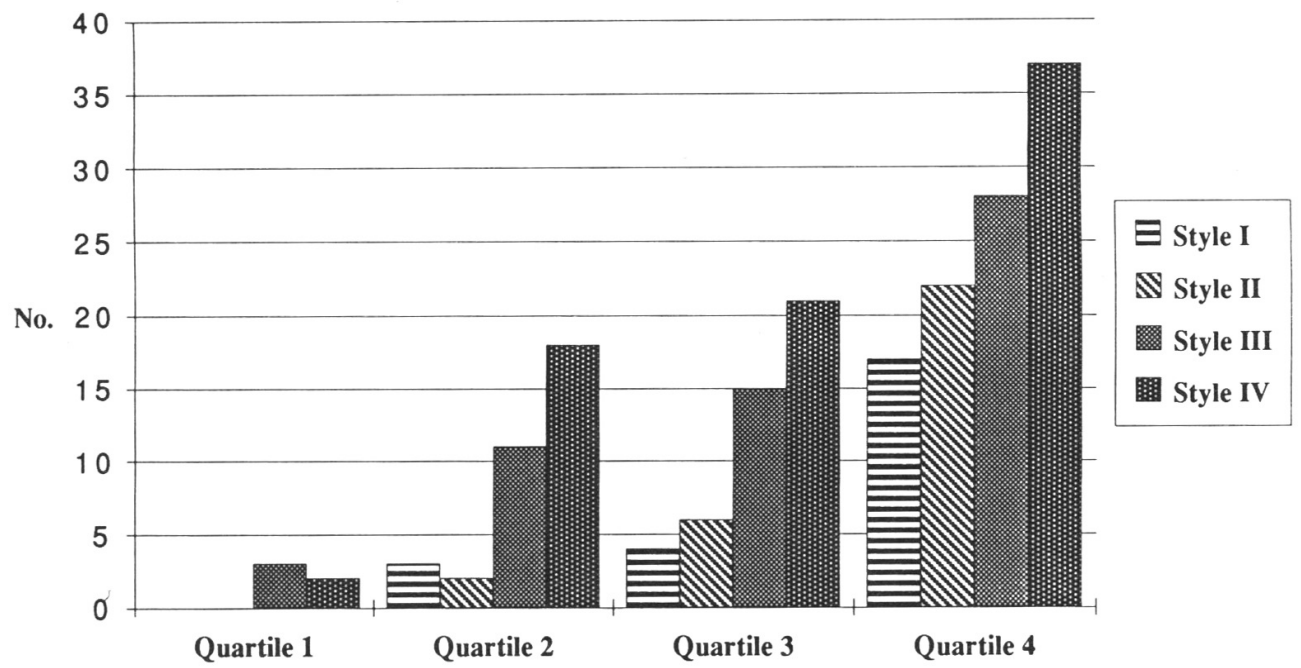

FIG. 8. Distribution of the four styles in Pompeii by quartile.

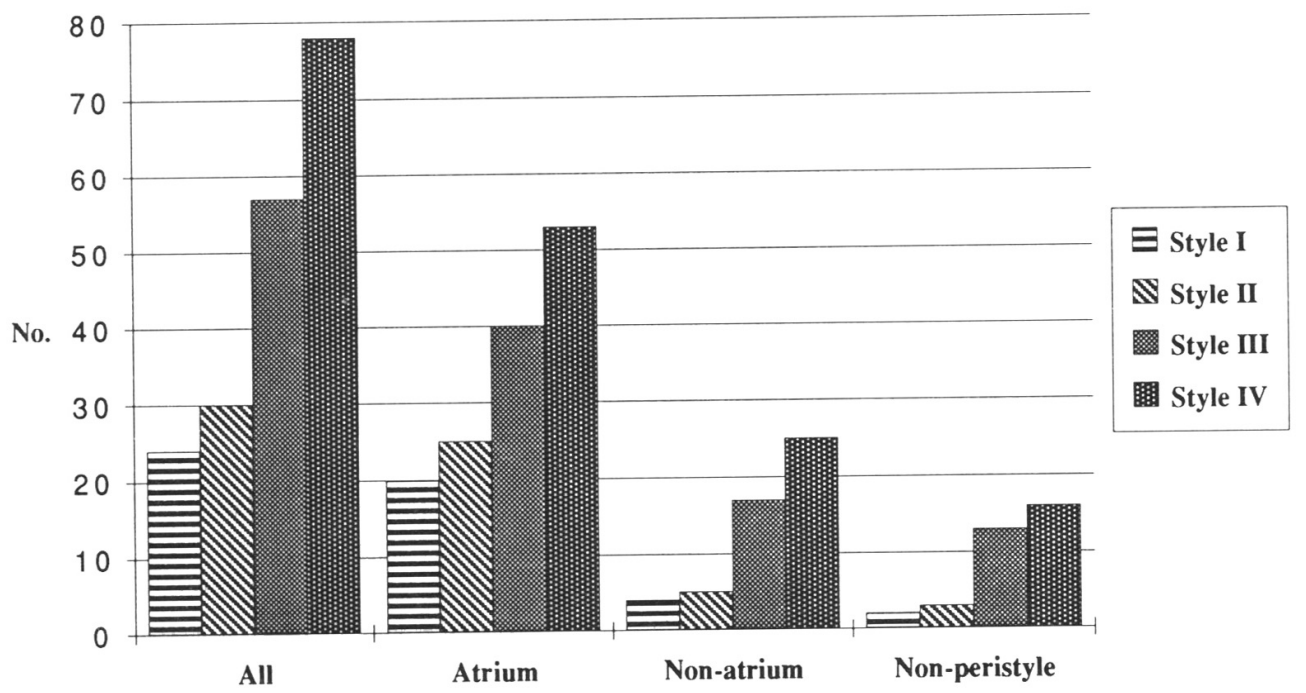

Fig. 9. Distribution of the four styles in Pompeii by house type. 
the distribution of the styles between non-atrium and atrium houses. The proportion changes, not gradually from one style to the next, but suddenly between second and third styles-from 1:5 under the Republic to 1:2 under the Empire. We have seen that there is a close association between decoration and the reception function implicit in the atrium. It now emerges that the spread of decoration beyond atrium houses is much more marked in the imperial than the republican period.

TABLE 7

Proportionate distribution of the four styles.

\begin{tabular}{lcccc}
\hline & $\begin{array}{c}\text { Quartiles 1-3 } \\
(10-345)\end{array}$ & $\begin{array}{c}\text { Quartile } 4 \\
(350-3000)\end{array}$ & $\begin{array}{c}\text { Non-atrium } \\
\text { houses }\end{array}$ & $\begin{array}{c}\text { Atrium } \\
\text { houses }\end{array}$ \\
\hline Stylc I & 1 & 2.4 & 1 & 5 \\
Style II & 1 & 2.8 & 1 & 5 \\
Style III & 1 & 1 & 1 & 2.4 \\
Style IV & 1 & 0.9 & 1 & 2.1 \\
\hline
\end{tabular}

The evidence points strongly towards a progressive spread of decoration. Even in Cicero's day, wall decoration had spread well beyond the villas of the rich into the fabric of urban Pompeii. ${ }^{63}$ But there is still some justification for referring to it at this period as an 'elite' cultural phenomenon. ${ }^{64}$ The Empire brings what might be described as a quantum leap. Fourth style decoration was surely yet more common than third; but it extended a tendency towards social diffusion established in the first generation of the empire.

\section{(d) From luxus to kitsch}

Few would wish to deny that the culture of the Roman elite was 'luxurious'. But when we come to discuss the decoration of hundreds of rooms in dozens of houses in second-rate Campanian towns, ranging from the breathtaking to the crude, simple and banal, can we still meaningfully speak of luxury? We naturally think of the architecture of a house with an ornate four-sided peristyle like the Casa del Menandro as 'luxurious'; but we might refuse to use the same language of its smaller neighbour, the Casa del Fabbro, with its single brick-pillared portico looking out over a modest garden patch. Of course there is a great gulf between the luxury of the elite houses and the simpler aspirations of the small. But what matters

\footnotetext{
${ }^{6}$ Note, however, the fragments of first style decoration emerging in houses of middling size in the blocks near the amphitheatre, e.g. I 20.4: Rivista di Studi Pompeiani 2 (1988), 189. There is also a fair scatter of first style in the houses in Region I south of the Via di Castricio which fall outside this survey.

${ }^{64}$ Contrast, e.g., M. Beard and M. Crawford, Rome in the Late Republic (1985), 20: 'The explosion of culture did not involve the poor or the lower classes, as either producers or consumers. It involved, rather, progressively broader bands of the Roman and Italian elite...' Even for the Republic, this statement is too uncompromising.
} 
is to understand that they do not belong to different cultural universes. It is precisely the cultural language of the elite which the others are imitating, even if by doing so they reduce it to the banal, trite and everyday. The worsted stockings of the English working classes, we have seen, owed their inspiration to the silk stockings sported on the calves of outrageous courtiers; but both luxury and outrage had been watered down to a scarcely perceptible dose. Modern wallpaper has its origins ultimately in the silk hangings of the aristocracy, and more immediately in the large and elaborate paper murals of the mid-nineteenth century; the advent of steam machines in 1858 made possible the cheap and repetitive patterns that were to flood the market. ${ }^{65}$

It is by looking at the fourth style of wall decoration that we can see this pattern most clearly. I have already argued that the decoration of the imperial period represents a great increase in range of quality and expressivity in comparison with the relatively limited styles of the Republic. ${ }^{66}$ Between the best and worst of the first style there is not much difference, and even with the second style, the range is little more. By the time we reach the fourth style, the range is huge, between simple white-ground walls divided with red stripes and embellished, if at all, with the sketchiest of vignettes, to richly coloured and minutely worked masterpieces like the classics of the Casa dei Vettii. It might be argued that there was an overall decline in quality from the late republican and Augustan peak (Villa dei Misteri etc.); indeed, Schefold was so disparaging about the quality of Flavian painting as to use expressions like 'vespasianischer Kitsch'. ${ }^{67}$ But while progressively more of low quality was produced as demand expanded, the distance between the top and bottom of the market widened.

The fourth style may be analysed, I have suggested, ${ }^{68}$ as incorporating a series of hierarchies or ranges of choice, affecting choice of colour, decorative framework, and motifs. Thus, if we concentrate on the central field of the wall alone (though socle and upper register introduce their own variants) we can distinguish a range of dominant background colour, from the simple white, through the frequent red and yellow (often combined), to the rare blacks, blues and greens. Then in terms of elements used to articulate and divide the wall into separate panels, there is a range from simple lines, through border patterns, mostly of the 'bordi a tappeto' type, to embellishments such as candelabra and columns, to the elaborate architectural vistas that take on a life of their own in this style. Finally, in terms of motifs with which to embellish the central field created by these borders, there is a progression from little vignettes, of swans, griffins, cupids, tragic masks, sacred objects and so on, through more ambitious roundels and small panel paintings, the roundels often containing faces, the panels still lives, little landscapes, villa scenes, etc., to reach a climax with the larger and more elaborate panel paintings, above all of

${ }^{65}$ On the popularisation of wallpaper, see Zeldin, Taste and Corruption, $81 \mathrm{f}$.

${ }^{66} \mathrm{Cf}$. 'The social structure...', PBSR 1988, 74.

${ }^{67}$ Schefold, Vergessenes Pompeji, 124, characteristic of the tone of the chapter on 'Vespasianic' decoration. Maiuri took an equally dim view of the vulgarisation of imperial art: e.g. L'ultima fase edilizia 216, '....al mutamento e pervertimento di gusto nel genere e nello stile della decorazione degli ambienti...'

${ }^{68}$ PBSR 1988, 74-6. 
mythological scenes. (This account is a simplification of a complex and varied reality, but one designed to bring out something of that complexity.)

Both the unity and the range of the fourth style lie in the way that decoration, however grand or humble, can be drawn from this same repertoire. Precisely the same terminology can be found repeated in the careful descriptions of fourth style decorations in Pitture e Pavimenti; the richest decoration is distinguished by its use of more of the standard elements, so that description becomes longer. As a very crude illustration, we can look at the fourth style rooms in just one of the samples, that in Regio I. 36 houses there have between them 115 rooms decorated in this style. Of these, 5 are shop paintings and 10 garden paintings which fall outside the idiom described above; the remaining 100 rooms can be compared. (A room may of course overlap within the ranges, e.g. with alternating red and black panels, borders, columns and architectural vistas, vignettes and panels and mythologicals; hence the totals do not add up to 100.)

If it is true that there is a hierarchy among these elements, their distribution across the house-size quartiles ought to be unequal. Standard elements like borders and vignettes should be met in houses of all sizes; rare ones like blue/black/green decoration, columns and architectural vistas, panels and mythological paintings ought to be more frequent in the larger houses. This is in fact the case in this sample. In Table 8 is set out the distribution of these rooms across houses in our standard quartile ranges (for ease of comparison, the same size ranges are used as before).

TABLE 8

Fourth-style features and house size.

\begin{tabular}{lccc}
\hline $\begin{array}{l}\text { Quartile } \\
\text { (size sq.m) }\end{array}$ & 2 & 3 & 4 \\
$\mathcal{N}=$ rooms (houses) & $(50-170)$ & $(175-345)$ & $(350-3000)$ \\
\hline Colour & $21(6)$ & $26(10)$ & $68(16)$ \\
Whiteground & & & \\
Red/yellow & $8(38 \%)$ & $8(31 \%)$ & $24(35 \%)$ \\
Blue/black/green & $10(48 \%)$ & $13(50 \%)$ & $32(47 \%)$ \\
Framework & 0 & $2(8 \%)$ & $9(14 \%)$ \\
Borders & $14(67 \%)$ & $18(69 \%)$ & $49(72 \%)$ \\
Candelabra & $7(33 \%)$ & $8(31 \%)$ & $20(29 \%)$ \\
Colums & $3(14 \%)$ & $4(15 \%)$ & $16(23 \%)$ \\
Vistas & $1(5 \%)$ & $6(23 \%)$ & $26(38 \%)$ \\
Motifs & $4(19 \%)$ & $2(8 \%)$ & $3(4 \%)$ \\
Blank & $9(43 \%)$ & $19(73 \%)$ & $43(63 \%)$ \\
Vignettes & $6(29 \%)$ & $7(27 \%)$ & $30(44 \%)$ \\
Panels & $3(14 \%)$ & $1(4 \%)$ & $12(18 \%)$ \\
Mythologicals & & & \\
\hline
\end{tabular}

Note: percentage figures refer to the proportion of all fourth-style rooms in the quartile concerned which have that feature. Thus the 8 whiteground rooms in quartile 2 represent $38 \%$ of the 21 fourth-style rooms in the quartile. The percentages thus indicate the relative frequency of that feature within houses of that quartile. 
Of background colours, red/yellow accounts for more than half (55 rooms), white ground is also frequent (40 rooms), blue/black/green rare (11). Among dividing elements, easily the commonest is the decorative border ( 81 rooms), while candelabra (35), columns (23) and architectural vistas (33) are each found in a third or less of the rooms. The conventional account which regards the architectural vista as the characteristic of the fourth style is to this extent misleading: in fact the decorative border is the most predictable element, and it is on this that the most promising recent research concentrates. ${ }^{69}$ Finally among embellishments, vignettes (71 rooms) far outnumber roundels and panels (43), and of course mythologicals (16); only 9 rooms are completely without trace of any of these. Again, it is with vignettes, rather than the mythological paintings that have engrossed attention, that serious analysis of the fourth style must start.

This analysis, complicated though it looks, oversimplifies the varieties of fourth style decoration. But it serves well enough to illustrate the way in which certain elements are equally common in houses of any size (white, red/yellow backgrounds, decorative borders and vignettes) and form the staple, so to speak, of this style, while others are relative rarities which tend to cluster in the largest houses (blue/black/green, columns and vistas, panels and mythologicals). In a sample this small, the individual house can easily make a disproportionate impact on the figures. Thus, the charmingly decorated, little Casa di Venere in Bikini (I 11.6) swells the figures for mythologicals in the second quartile, while the Casa del Efebo (I 7.10-12) is exceptional among large houses in the frequency of its white ground rooms and swells the figures for the top quartile. A larger sample and a more sophisticated analysis of the component elements would be necessary for better understanding of the fourth style.

All this analysis seeks to demonstrate is that the fourth style has a unified repertoire; that great and small houses draw on the same idioms, and that richly decorated houses distinguish themselves by employment of more and richer elements. How we should explain the range of this repertoire is of subordinate importance: one might argue that as the demand for decoration spread to the less well-off, the quality of a former luxury fell; or that the ateliers of decorators deliberately introduced simpler and cheaper schemes of decoration in order to tap a wider market. From the point of view of the present analysis it makes little difference (and both explanations may be simultaneously true). The point is that the fourth style is well adapted for a market that ranges, as we see in Pompeii, from the rich to the poor, and is no longer the preserve of an elite.

\section{FINDS}

In any survey of the social and economic aspects of houses in Pompeii and Herculaneum, study of the finds should play a crucial, perhaps the crucial part. The attempt above to gain a picture of household wealth and social standing relies

\footnotetext{
${ }^{69}$ E.g. Strocka, Casa del Principe di Napoli esp. 37f on 'Filigranborten'; Ehrhardt, Stilgeschichtliche Untersuchungen (above n. 60), passim, and much of the work of M. de Vos.
} 
almost entirely on structures and decoration. Yet these are imprecise (though not, I hope to have shown, worthless) measures. Finds have the potential of supplying precise and reliable answers to many of the questions I have asked, and compared with almost any other archaeological site, the finds of Pompeii and Herculaneum are extraordinarily rich. At the very least, finds should indicate whether any unit was actually inhabited - and that many were abandoned in the aftermath of the earthquake of A.D. 62 is highly likely. Then finds give the vital clues as to the economic and social activities within the house, in the presence of equipment, tools, containers and plant indicating economic activity, as well as the apparatus and furniture of social life. To some extent, of course, this evidence is already incorporated into traditional identifications of shops, workshops etc. used in the analysis above; though as I have stressed, it is only where activities leave behind unmistakable structural traces, such as shop-fronts, counters, ovens, grinders, vats and the like, that we can be sure that they have in fact been observed.

Finally, finds offer an ideal measure of wealth and standing. Structures and decoration both outlast their original creators; it is not infrequent that, as in the Casa del Criptoportico, modest inhabitants are found amid the ruins of erstwhile splendour. ${ }^{70}$ Finds, particularly those of any intrinsic value, come and go with the current inhabitants, and offer a far more sensitive measure of their wealth. The best pointer to the wealth and standing of the inhabitants of the Casa del Menandro is not the exceptional size of the house, nor the fineness of its decoration, but the unparallelled silver service found in its cellars. The poverty of shop I 10.9 in the corner of the same block is seen not only in its minute size and lack of decoration, but in the total absence of furniture and finds. ${ }^{71}$ It would therefore be of great value to examine the distribution between houses of different sizes and types of the artefacts which could be taken as status markers: statuary, of marble and bronze; marble tables and furniture; precious metal objects, whether coins or plate; jewelry of all sorts; and a variety of miscellaneous objects like ivory combs, alabaster scent-bottles, or even Arretine pottery.

The reason why I make virtually no use here of this vital evidence lies in the state of the scholarship. Excavation methods have been crude; nevertheless, copious evidence has been unearthed. Reporting has been patchy and inadequate; nevertheless, lists of finds are preserved in the excavation journals on site. Evidence is there: but it is so complex and rich that it is impossible to deploy until it has been afforded the same degree of serious study as has been lavished on the decoration. The difficulties can be exemplified briefly. House I 10.8 was traditionally identified as that of the weaver Successus. ${ }^{72}$ The evidence lay in a graffito in the neighbouring tavern I 10.2 , of no necessary relevance, and in the finds of the house, which include 53 loom weights in the atrium. The inadequacy of this evidence has been rightly emphasised by Jongman in his recent study of Pompeian economy and

${ }^{70}$ A theme much stressed by Maiuri, L'ultima fase edilizia, 162 f.

${ }^{11}$ Elia, $\mathcal{N S c} 1934,320 \mathrm{f}$. On the importance of furniture as a status indicator, cf. Zeldin, Taste and Corruption, 82: 'What the people of this period [1848-1945] liked in their furniture was thus first of all a symbol of status. The poor had virtually no furniture; even the middle classes took a long time to collect more than the bare essentials-a bed, a table and cheap chairs.'

${ }^{72}$ M. della Corte, Case ed Abitanti, 251, cf. NSc 1934, 317. 
society. ${ }^{73}$ The loom weights might indeed belong to a traditional domestic loom. But did they? To answer this question would require systematic study of loom weights and other traces of weaving in Pompeii. The situation is obviously different from that in fourth-century B.c. Olynthos, where almost every house had loom weights. ${ }^{74}$ But the evidence in Pompeii has never been studied, so that we have no idea to what extent weaving was the female domestic activity of Roman ideal, and to what extent a commercial undertaking.

The use of finds evidence is much complicated by the manner in which it has been disrupted over the course of centuries. Herculaneum is riddled with the tunnels of eighteenth-century explorers; Maiuri, who understood something of the importance of finds, complains repeatedly of their destruction of the evidence. ${ }^{75}$ But tunnelling was not confined to the eighteenth century; the Insula of the Menander in Pompeii shows numerous traces of holes hacked through from room to room and house to house. It is unclear whether these are the responsibility of looters in antiquity, or even trapped inhabitants trying to make their way out. But the consequence is that much appears to be missing or displaced. Thus the elegant Casa degli Amanti (I 10.11) is almost devoid of finds, apart from humdrum hinges, lamps, and the odd bronze coin, while the smaller and in every other respect more modest Casa del Fabbro (I 10.7) is a veritable treasure house, with a variety of jewelry, silver coins (including a collection of republican denarii), perfume bottles, writing implements, balances and weights, measuring and surveying implements, as well as the set of joiner's tools from which the business of the inhabitant has been inferred. ${ }^{76}$ Either the Casa degli Amanti has been thoroughly looted or the inhabitants packed their bags well, whether during or before the eruption. Without systematic investigation of the presence and absence of finds, and of the patterns left behind by abandonment, bag-packing, looting and primitive excavation, we are simply not in a position to assess the significance of finds. When this has been done, it may be possible to give more sophisticated and reliable answers to some of the questions raised in this paper. ${ }^{77}$

${ }^{73}$ Jongman, Economy and Society, 163.

${ }^{74}$ D. M. Robinson and J. W. Graham, Excavations at Olynthos VIII. The Hellenic House (1938), 209: loom weights found 'in nearly every room of every house excavated'. See also my remarks in Ant. Joum. 66 (1986), 434.

${ }^{75}$ Ercolano. I Nuovi Scavi, e.g. 220, 252, 260 etc.

${ }^{76}$ NSC 1934, 292-308 on the finds of I 10.7, a stunning collection meticulously recorded; 336-9 on the disappointing haul of I 10.1I, esp at 336: 'The condition of complete confusion in which the material from the eruption presented itself, as far as several metres from the ground, the frequent presence of breaches made in series along each side of the house, in such a way as to render all the rooms intercommunicating, the disappearance of any trace of the furniture commonest in the houses of Pompeii, beds, portable tables and chairs, points clearly to the partial recovery of furniture ... in a return after the catastrophe.'

${ }^{77} \mathrm{I}$ am greatly indebted in this section to Pim Allison of Sydney University, who has persuaded me both of the importance and the difficulty of closer examination of the finds. Valuable results are to be expected from her own research into these questions. 


\section{CONCLUSIONS}

In attempting, in what does not pretend to be more than an experimental and tentative fashion, a statistical approach to the social and cultural data of the Vesuvian towns, my aim has been to establish relationships, not absolute numbers. It is not the intention of the paper to suggest that the average size of a Roman house was $\mathrm{x} \mathrm{m}^{2}$; or that $\mathrm{x} \%$ of Roman shops or houses were decorated; or that $\mathrm{x} \%$ of Roman houses were involved in trade and commerce. Anyone who tried to extract such inferences from my figures would be rash. The value of these statistics is to point to and test links, similarities and dissimilarities, correlations and absences of correlation. The apparent precision of derived numbers can be seductive; I have tried to emphasise throughout that they are only a starting point for interpretation, for further testing and questioning. However pedantic, this caution is necessary. But despite all caveats, the results seem to me highly suggestive, and to point beyond the confines of Campania to a wider understanding of Roman society and culture.

First, they cast a light on the nature of the social fabric of a Roman urban community. Study of Pompeian houses as a group throws into relief the mixed nature of the housing, the jumble of large and small, elegant and crude, rich and poor, residential and non-residential. That surely indicates something important about Roman urban society, at least of this period: comparison with sites elsewhere is needed to test how far in space and time the pattern extends.

Odd in comparison with the post-industrial city, such an intermixture of rich and poor was familiar to other premodern periods and societies. Jacques Heers has shown how the housing pattern of the medieval Italian town reflects its social structure and the vitality of neighbourhood ties. ${ }^{78}$ But the situation in medieval Italy is made different by precisely the object of Heers' study, the power of the family clan. It would not be easy in Pompeii to point to multiple holdings of a single extended family, nor the strength of dominance exercised over their neighbourhoōds by these families. The links are rather looser, such as might suit a society characterised by slavery, manumission and patronage, not (or perhaps no longer) by clan. In Pompeii too we can recognise the domus magna surrounded by its domunculae: the Casa del Menandro with its penumbra of lesser neighbours looks like a case in point, and it is a plausible hypothesis that it owned most if not all of its block. ${ }^{79}$ But unlike medieval Pisa, Pompeii cannot be split into a series of quartieri, each dominated by its own great house. This would be to overlook the enormous number of houses of middling size and middling rank, in which a substantial part of the population must have lived. It is the importance of this class that perhaps emerges most vividly from this survey.

Paul Zanker, in one of the finest studies of Pompeian housing of recent years, showed how potent was the aristocratic villa as a model for the lifestyle of even

${ }^{78} \mathrm{~J}$. Heers, Family Clans in the Middle Ages (English translation 1977), cited by Jongman, Economy and Society, $309 \mathrm{f}$.

${ }^{79}$ So Ling, Ant. Fourn. 62 (1983), $56 \mathrm{f}$. 
quite modest houses in Pompeii. ${ }^{80}$ Here we find gardens with miniature euripi and nili, adorned with statuary shrunk to the scale of gnomes, nymphaea with miniature dining couches, disproportionate garden paintings evoking imaginary viridaria-all testimony to the way in which Lucullan luxury created the image of success and happiness to which even those with slender resources aspired. The argument of this paper is to extend yet further Zanker's model. Take the cluster of small houses nestling alongside the handsome Casa di Paquio Proculo (I 7.1). I 7.7, the Casa del Sacerdos Amandus $\left(c .230 \mathrm{~m}^{2}\right)$, is very much a middle-range house, towards the bottom of the third quartile of our sample; with atrium and a pretty peristyle with colonnades on two sides, and six rooms nicely decorated in the third style, the largest including a (now familiar) group of mythological scenes, Polyphemus and Galateia, Perseus and Andromeda, the fall of Icarus, and the Apples of the Hesperides. I 7.3, the Casa di Fabius Amandio, is considerably smaller $\left(c .125 \mathrm{~m}^{2}\right)$, close to the minimum at which an atrium is possible: but tight organisation makes possible not only atrium but a miniature garden (without colonnades); both these and five rooms have third style decoration, and four of the rooms have simple mosaics on the floor. I 7.5 is a workshop, probably owned by I 7.7, and perhaps previously part of it. At $80 \mathrm{~m}^{2}$ the ground floor has only space for a central yard and two rooms. Both of these are decorated, again in the third style; even the bird and cherry panels on the simple white ground walls of the smaller of these can be paralleled in luxury villas like Oplontis.

It would be pure speculation to try to pinpoint the status of the individual inhabitants or owners of any of these three houses. What the statistics do allow is to identify the broad context of inhabitants of houses of these sorts. By no stretch of the imagination could we see in them members of an elite. The members of the ordines of the city, both decurions and Augustales, wealthy landowners and traders, ought to be found in the top $10 \%$, or at the most generous, $25 \%$ of the houses. Too many of the indicators of wealth and prestige cluster in the houses in the top quartile to make it plausible to look lower down the scale for an elite, even a local one. Nor, on the other hand, can we be looking at the poor. Too many houses lack decoration, at least on the ground floor, let alone atria, to allow us to populate such handsome premises with them, unless as lodgers and tenants of upper flats. Necessarily, we are dealing with a large and disparate group between elite and poor. I hesitate to use terms such as 'middle/lower middle class' or 'bourgeoisie/ petite bourgeoisie' because of their profoundly anachronistic connotations. In the elder Pliny's terms, they were the plebs, not the plebs humilis but the plebs media. To judge by the nomenclature of almost all the documentary evidence we have from the Campanian towns, a high proportion of them are likely to have been of servile origin. To judge by the archaeological evidence, they were extensively involved in the trade, craft and commerce of the city.

Among such relatively prosperous plebeians, habits of 'luxury' house decoration derived from conscious imitation of the Roman elite spread. The distribution of the four styles suggests strongly that although decoration was by no means uncommon even under the Republic, it was under the early Empire that the major diffusion

go 'Die Villa als Vorbild...' (above n. 3). 
among 'plebeian' households got under way. This would appear to be a period of increasing prosperity for the city. The spread of decoration does surely reflect a rise in prosperity among such people. But decoration represents more than display of wealth. Together with architecture, it is a method of fashioning space adequately for the social activity it is expected to contain, and specifically for the reception of visitors, and hence of displaying, or laying claim to, social rank. Vitruvius' sketch of the social ranks for which the architect builds might lead us to expect beneath the level of public figures, lawyers and financiers, a large mass of people 'of common fortune' who paid their respects to others and did not receive their own visitors. That picture tends to be refuted by the evidence of Pompeii and Herculaneum, where even small flats above shops may share in their touches of 'luxury'.

But social spread brings with it banalisation. I have tried to show how in the fourth style even the decoration of modest houses draws on the same repertory as do the great show houses. The ultimate model for them all is the Hellenising culture of the senatorial elite of late Republic and early Empire. But as the imitation spreads out and becomes banal, so its social function shifts. At a remove, it may import something of the lifestyle of the prosperous and successful into a humble home. But more than that, I would suggest, it brought a sense of belonging: of membership of a society in which ideology and culture were defined by the elite. Particularly for those whose claims to Roman identity were new and tenuous, the manumitted slaves, it must have been necessary to surround themselves with visible symbols of their Romanness. To become a Roman, a slave must pass through rebirth by imitation; the master supplied the model. However foreign the trappings of luxury may have been in origin, the fact that the aristocracy, which had always set the model within Roman society, had made them their own converted them, paradoxically, into symbols of the Roman.

Behind the explosion of new fashions in domestic luxury which Pompeii and Herculaneum would appear to document, there seem to me to lie a complex of factors of social and economic change which are by no means confined to Campania. One is a rise in economic prosperity, and specifically urban prosperity, in late republican and early imperial Italy. A second is a massive expansion of the Roman citizenship, with its implications for the redefinition of what being 'Roman' actually signified. A third is a cultural revolution among the elite that has its roots in intense competition, in the need, in a rapidly changing political scene, to assert claims to social leadership, and to stay one step ahead of competitors as the new status symbols in their turn became progressively banalised. Together these factors generated a social and cultural revolution that spread not only through the cities of Italy, but with surprising speed into the provinces. Understanding of the process of 'Romanisation' in the provinces must start with interpretation of cultural change in Roman Italy. Pompeii and Herculaneum offer precious evidence towards that interpretation, and just as they have been successfully exploited to construct a paradigm of the chronology of decoration, they offer a potential paradigm of its sociology. But the value of the paradigm offered here can only be tested by extending the investigation outside Campania. 